\title{
Assessment of Domestic Policies Guiding the Fair and Equitable Sharing of Benefits From Utilization of Genetic Resources and Traditional Knowledge
}

\author{
Hasrat Arjjumend ${ }^{1}$, Konstantia Koutouki ${ }^{2}$ \\ ${ }^{1}$ Centre for International Sustainable Development Law, McGill University Faculty of Law, Montreal (Quebec) H3A \\ 1X1, Canada. \\ ${ }^{2}$ Faculty of Law, Université de Montréal, Montreal (Quebec) H3T 1J7, Canada \\ Correspondence: Hasrat Arjjumend, Centre for International Sustainable Development Law, McGill University Faculty \\ of Law, Montreal (Quebec) H3A 1X1, Canada. E-mail: harjjumend@gmail.com
}

$\begin{array}{lcc}\text { Received: Mar. 4, } 2020 & \text { Accepted: May 3, } 2020 & \text { Online Published: May 14, } 2020 \\ \text { doi:10.11114/ijlpa.v3i1.4856 } & \text { URL: https://doi.org/10.11114/ijlpa.v3i1.4856 }\end{array}$

\begin{abstract}
The objective of the Nagoya Protocol guides Parties to regulate illegitimate access and utilization of biological resources or associated traditional knowledge, and also directs Parties to share with fairness, equity and justice the monetary or non-monetary benefits arising out of utilization of genetic resources. In a nod to the United Nations Declaration on Rights of Indigenous People, the Nagoya Protocol binds the Parties to create access and benefit sharing (ABS) laws, policies or administrative measures as envisaged in Articles 5.2 and 5.5 of the Protocol, and obliges the States to allow for benefits to flow to Indigenous peoples and local communities (ILCs). Present paper is based on an opinion survey of academic/research institutions, civil society organizations and concerned individuals apart from competent national authorities of Asian countries. Review of secondary information, especially domestic ABS laws of relevant countries, and participant observation were other means of legal and policy analysis. The findings of this paper illustrate that the accrued benefits from the utilization of genetic resources or traditional knowledge are not adequately realized by Indigenous people or local communities. State sovereignty occupies dominance when justice and equity principles are considered in benefit sharing mechanism. It leads to the infringement of Indigenous rights and conservation objectives. Discrepancies in domestic ABS laws and in the frameworks for their implementation could be addressed by ensuring the participation of ILCs in domestic ABS rulemaking, decision-making processes, and the participatory execution of ABS mechanisms at all levels. The resulting gains in efficiency in the ABS process could then better achieve the goal of conserving and sustainably using biodiversity, while also ensuring respect for the rights of Indigenous people.
\end{abstract}

Keywords: ABS, Nagoya protocol, benefit sharing, indigenous people, genetic resources, traditional knowledge, equity, justice

\section{Introduction}

The fair and equitable sharing of benefits arising from access to, and utilization of, genetic resources and associated traditional knowledge (ATK) has been one of the backbones of international law governing biological diversity, namely the Convention on Biological Diversity and the Nagoya Protocol on Access to Genetic Resources and the Fair and Equitable Sharing of Benefits Arising from their Utilization (Nagoya Protocol). At the time of entry into force of the Protocol, 57 countries (40 developing countries and 17 developed countries) had enacted some kind of domestic legal access and benefit sharing (ABS) measures, according to the CBD Secretariat ${ }^{1}$. In compliance with the Nagoya Protocol, by mid-2018 nearly 65 countries have made progress in promulgating domestic ABS legislation, policy or administrative measures (see section 3.4 below). Yet, it needs to be examined whether the domestic ABS measures have adequately incorporated the provisions requiring fair, equitable, just and mandatory sharing of benefits resulting from access and utilization of genetic resources or associated traditional knowledge (TK).

Articles 5.1, 5.2, 5.5 and 12 of the Nagoya Protocol explicitly address benefit sharing and its mechanisms. This paper argues that mutually agreed terms (MAT) should integrate the principles of equity and justice, be agreed upon with the

1 http://www.cbd.int/abs 
participation of Indigenous and local communities (ILCs), support the rights of Indigenous people as guaranteed by United Nations Declaration of Rights of Indigenous People (UNDRIP), and respect the principle of State sovereignty over biological diversity. This paper will further argue that within benefit sharing-related provisions in domestic ABS laws, one aspect is of paramount importance: the ultimate flow of benefits to ILCs.

Using evaluative and social impact assessment research methods, this paper explores and evaluates facets of benefit sharing provisions and mechanisms in domestic ABS legislation, policies and administrative measures, including questions such as: 1) whether users of genetic resources and associated TK share benefits with the providers in a fair and equitable manner; 2) whether justice and equity concerns are integrated in MAT negotiations before access to genetic resources and associated TK is granted; 3) whether MAT or other kinds of agreements (e.g. material transfer agreement, resource use agreement) are developed on equity principles; 4) whether domestic ABS laws, especially the laws of developed countries, adequately incorporate benefit sharing clauses; 5) whether domestic ABS laws contain provisions on mandatory benefit sharing with ILCs; 6) whether the participation of ILCs is given due importance in domestic ABS law or policy making processes; 7) whether the benefits accrued by States are duly shared with the ILCs; 8) what mechanisms are established by States to ensure that received benefits flow to ILCs; and 9) whether the rights of Indigenous peoples are protected in domestic ABS legislation. Inquiry into these questions was thus focused on qualitative parameters in order to explore the practical implications of international law in the context of domestic ABS laws, policies and administrative measures.

In this paper, the cross-cutting questions of fairness, justice, equity and the rights of ILCs are raised when considering rules dealing with access/utilization of genetic resources or associated TK held by provider countries and the ILCs residing there. It concludes that meeting these goals requires domestic ABS frameworks that ensure the mandatory sharing of benefits with ILCs. The paper aims at providing with the feedback to policy makers especially in member countries of Convention on Biological Diversity (CBD) and Nagoya protocol. Based on the empirical and legal analysis, benefit sharing apparatus of sovereign States must consider to overcome gaps, rectify the challenges and improve not only the domestic laws but also the justice delivery system in order to comply with the requirements of UNDRIP.

\section{Methodology}

As part of a project studying ABS at the Academy of International Studies of Jamia Millia Islamia, the field data for this study was gathered from 2012 to 2015 . The study employs exploratory research techniques, including two of three types of applied research: (1) evaluative research, and (2) social impact assessment research. Evaluative research measures the effectiveness of a program, policy, or way of doing something. The ABS regime at both the international and national levels continues to evolve, and questions exist about its efficacy, especially in regard to the implementation of the Nagoya Protocol. The second method employed in this study is social impact assessment research, which estimates the likely consequences of a planned change, and examines the outcomes of policy interventions. This study assesses how national ABS laws have addressed social justice and equity issues, particularly for marginalized ILCs. There are two dimensions in assessing social impacts: (1) how equity and justice concerns are addressed when accessing the genetic resources and associated TK from the territories of ILCs; and (2) how the intended benefits are to be shared fairly and equitably with the ILCs. The social impact of ABS measures is assessed through analysis of existing documents and secondary information, as well as through structured interviews and participant observation.

\subsection{Sampling for Structured Interviews}

Stratified random sampling was employed for the purposes of conducting the structured interviews, with lists of potential respondents being prepared beforehand. Different questionnaires were prepared for different types of respondents, i.e. one set of questionnaires for academic/research institutions, civil society organizations (CSOs) and concerned individuals, and a second set of questionnaires for the competent national authorities (CNAs) of the countries surveyed. Academic institutions, organizations and individuals working on or advocating ILC issues and causes were first listed and then contacted. The lists were subsequently narrowed down using various criteria imposed by the financial constraints of this study. The criteria included whether participants were able to respond to questions in English, and whether they had access to email. The participants consisted of 565 academic/research institutions all over the world, 2590 civil society organizations, 20,900 concerned individuals, and 50 CNAs of Asian countries. Except some (who were contacted physically), all were contacted by email. The authors also ensured that the sample included female participants, was geographically representative, and would be easy to access for follow-up purposes if needed. However, pursuant to our selection process and subject to participants' availability, research only proceeded with those who responded to the request for structured interviews.

It is important to note that the expert sampling technique was used to obtain the responses of various national focal points of governments from Asian countries. CNAs in 50 countries from South Asia, South-East Asia, West Asia, Central Asia and North Asia were contacted face-to-face and by e-mail. Of these, 12 countries responded by completing the questionnaire. Other countries, including Bahrain, Singapore, Qatar and South Korea, replied that they had not 
begun preparations for ABS legislation or policies in their respective countries; hence, they did not complete the structured interview questionnaire. Similarly, 24 academic/research institutions, civil society organizations and concerned individuals gave response to structured interviews. The list of responding institutions, organizations, individuals and CNAs is provided at Annex I.

\subsection{Structured Interviews}

Prior to contacting potential respondents, two questionnaires were developed (see Table 1: Opinions of Academic/Research Institutions, Civil Society Organizations, and Individuals; and Table 2: Opinions of CBD/NP Parties). There were ten questions in the first questionnaire, and six in the second. The questions were designed to be pertinent yet limited in number, in keeping with the needs of the study, the respondents' profile, and the ambience of $\mathrm{CBD}$ and $\mathrm{ICNP}^{2}$ forums where respondents were contacted face-to-face.

Table.1. Fair and Equitable Benefit Sharing: Opinions of Academic/Research Institutions, Civil Society Organizations, and Individuals

\begin{tabular}{c|c|c|c|c|c|c}
\hline \multirow{2}{*}{$\begin{array}{c}\text { Questions of } \\
\text { Opinion Survey }\end{array}$} & $\begin{array}{c}\text { Options of } \\
\text { Responses against } \\
\text { the Questions }\end{array}$ & \multicolumn{2}{|c|}{$\begin{array}{c}\text { Academic/Research } \\
\text { Institutions (n=10) }\end{array}$} & \multicolumn{2}{|c|}{$\begin{array}{c}\text { Civil Society } \\
\text { Organizations (n=8) }\end{array}$} & $\begin{array}{c}\text { Concerned Individuals } \\
(\mathbf{n}=6)\end{array}$ \\
\cline { 3 - 6 } & $\begin{array}{c}\text { No. of } \\
\text { Response }\end{array}$ & Response \%age & $\begin{array}{c}\text { No. of } \\
\text { Response }\end{array}$ & Response \%age & $\begin{array}{c}\text { No. of } \\
\text { Response }\end{array}$ & Response \%age \\
\hline
\end{tabular}

Article.5.1. In accordance with Article 15, paragraphs 3 and 7 of the Convention, benefits arising from the utilization of genetic resources as well as subsequent applications and commercialization shall be shared in a fair and equitable way with the Party providing such resources that is the country of origin of such resources or a Party that has acquired the genetic resources in accordance with the Convention. Such sharing shall be upon mutually agreed terms (MAT).

\begin{tabular}{|c|c|c|c|c|c|c|c|}
\hline $\begin{array}{l}\text { 1. Do you think } \\
\text { that the user Parties } \\
\text { (generally } \\
\text { developed countries) } \\
\text { would share the } \\
\text { benefits } \\
\text { appropriately to } \\
\text { provider Parties } \\
\text { (usually developing } \\
\text { countries)? }\end{array}$ & $\begin{array}{l}1 . \quad \text { Yes. Benefits } \\
\text { would be shared by } \\
\text { all or some user } \\
\text { countries, but I } \\
\text { doubt that these } \\
\text { benefits would be } \\
\text { shared with fair and } \\
\text { equitable way. } \\
2 . \quad \text { Yes. The } \\
\text { benefits would be } \\
\text { appropriately } \\
\text { shared with fair and } \\
\text { equitable way by } \\
\text { some user } \\
\text { countries. } \\
3 . \quad \text { Yes, I think } \\
\text { so. The benefits } \\
\text { would be } \\
\text { appropriately } \\
\text { shared with fair and } \\
\text { equitable way by all } \\
\text { users. } \\
4 . \quad \text { No, I don't } \\
\text { think so. } \\
5 . \quad \text { I don't know. }\end{array}$ & $\begin{array}{l}\text { 1. (6) } \\
\text { 2. (1) } \\
\text { 3. (0) } \\
\text { 4. (3) } \\
\text { 5. (0) }\end{array}$ & $\begin{array}{l}\text { 1. } 60 \% \\
\text { 2. } 10 \% \\
\text { 3. } 0 \% \\
\text { 4. } 30 \% \\
5.0 \%\end{array}$ & $\begin{array}{l}\text { 1. (5) } \\
\text { 2. (1) } \\
\text { 3. (1) } \\
\text { 4. (1) } \\
\text { 5. (0) }\end{array}$ & $\begin{array}{ll}\text { 1. } & 62.5 \% \\
\text { 2. } & 12.5 \% \\
\text { 3. } & 12.5 \% \\
\text { 4. } 12.5 \% \\
\text { 5. } 0 \%\end{array}$ & $\begin{array}{l}\text { 1. (4) } \\
\text { 2. (0) } \\
\text { 3. (1) } \\
\text { 4. (1) } \\
\text { 5. (0) }\end{array}$ & $\begin{array}{l}\text { 1. } 66.6 \% \\
\text { 2. } 0 \% \\
\text { 3. } 16.7 \% \\
\text { 4. } 16.7 \% \\
\text { 5. } 0 \%\end{array}$ \\
\hline $\begin{array}{l}\text { 2. Will the user } \\
\text { Parties (usually } \\
\text { developed nations) } \\
\text { take into account the } \\
\text { justice and equity } \\
\text { concerns during } \\
\text { preparation of MAT } \\
\text { before access of }\end{array}$ & $\begin{array}{l}\text { 1. Not at all, no } \\
\text { user Parties will } \\
\text { incorporate justice } \\
\text { and equity concerns. } \\
\text { 2. Yes, only some } \\
\text { user Parties will } \\
\text { incorporate justice } \\
\text { and equity concerns }\end{array}$ & \begin{tabular}{|ll} 
1. & $(4)$ \\
2. & $(3)$ \\
3. (2) \\
4. (0) \\
5. (0) \\
6. (1)
\end{tabular} & $\begin{array}{l}\text { 1. } 40 \% \\
\text { 2. } 30 \% \\
\text { 3. } 20 \% \\
\text { 4. } 0 \% \\
5.0 \% \\
\text { 6. } 10 \%\end{array}$ & $\begin{array}{l}\text { 1. (1) } \\
\text { 2. (3) } \\
\text { 3. (1) } \\
\text { 4. (1) } \\
\text { 5. (1) } \\
\text { 6. (1) }\end{array}$ & $\begin{array}{ll}\text { 1. } & 12.5 \% \\
\text { 2. } & 37.5 \% \\
\text { 3. } & 12.5 \% \\
\text { 4. } & 12.5 \% \\
\text { 5. } & 12.5 \% \\
\text { 6. } & 12.5 \%\end{array}$ & $\begin{array}{ll}\text { 1. } & (\mathbf{0}) \\
\text { 2. } & (3) \\
\text { 3. } & (\mathbf{0}) \\
\text { 4. } & (1) \\
5 .(\mathbf{0}) \\
\text { 6. }\end{array}$ & $\begin{array}{l}\text { 1. } 0 \% \\
\text { 2. } 50 \% \\
\text { 3. } 0 \% \\
\text { 4. } 16.7 \% \\
\text { 5. } 0 \% \\
\text { 6. } 33.3 \%\end{array}$ \\
\hline
\end{tabular}

2 Open-Ended Ad Hoc Intergovernmental Committee for the Nagoya Protocol on ABS (ICNP) 


\begin{tabular}{|c|c|c|c|c|c|c|c|}
\hline \multirow{2}{*}{$\begin{array}{c}\text { Questions of } \\
\text { Opinion Survey }\end{array}$} & \multirow{2}{*}{$\begin{array}{c}\text { Options of } \\
\text { Responses against } \\
\text { the Questions }\end{array}$} & \multicolumn{2}{|c|}{$\begin{array}{l}\text { Academic/Research } \\
\text { Institutions }(n=10)\end{array}$} & \multicolumn{2}{|c|}{$\begin{array}{c}\text { Civil Society } \\
\text { Organizations }(n=8)\end{array}$} & \multicolumn{2}{|c|}{$\begin{array}{c}\text { Concerned Individuals } \\
(\mathrm{n}=6)\end{array}$} \\
\hline & & $\begin{array}{c}\text { No. of } \\
\text { Response }\end{array}$ & Response \%age & $\begin{array}{c}\text { No. of } \\
\text { Response }\end{array}$ & Response \%age & $\begin{array}{c}\text { No. of } \\
\text { Response }\end{array}$ & Response \%age \\
\hline $\begin{array}{l}\text { genetic resource } \\
\text { held by provider } \\
\text { Parties (usually } \\
\text { developing } \\
\text { countries)? }\end{array}$ & $\begin{array}{l}\text { with reservations. } \\
\text { 3. Yes, only some } \\
\text { user Parties will } \\
\text { incorporate justice } \\
\text { and equity concerns } \\
\text { without reservations. } \\
4 \quad \quad \text { Yes, all user } \\
\text { Parties will } \\
\text { incorporate justice } \\
\text { and equity concerns } \\
\text { with reservations. } \\
5 . \quad \text { Yes, all user } \\
\text { Parties will } \\
\text { incorporate justice } \\
\text { and equity concerns } \\
\text { without reservations. } \\
6 . \quad \text { I cannot say. }\end{array}$ & & & & & & \\
\hline $\begin{array}{l}\text { 3. Will the } \\
\text { developing countries } \\
\text { be able to draft the } \\
\text { MAT on equity } \\
\text { principles, as } \\
\text { opposed to the } \\
\text { bargaining positions } \\
\text { of user countries } \\
\text { (usually developed } \\
\text { nations)? }\end{array}$ & $\begin{array}{l}\text { 1. Only some } \\
\text { developing } \\
\text { countries may have } \\
\text { capacities to draft } \\
\text { MAT on equity } \\
\text { principles. } \\
\text { 2. Developing } \\
\text { countries may have } \\
\text { capacities to draft } \\
\text { MAT, but not on } \\
\text { equity principles. } \\
\text { 3. Developing } \\
\text { countries may have } \\
\text { no capacities to } \\
\text { draft MAT on } \\
\text { equity principles. } \\
\text { 4. I cannot say. }\end{array}$ & $\begin{array}{ll}\text { 1. } & (\mathbf{6}) \\
\text { 2. } & (3) \\
\text { 3. } & (\mathbf{0}) \\
\text { 4. } & (\mathbf{1})\end{array}$ & $\begin{array}{ll}\text { 1. } 60 \% \\
\text { 2. } 30 \% \\
\text { 3. } 0 \% \\
\text { 4. } 10 \%\end{array}$ & $\begin{array}{ll}\text { 1. } & (4) \\
\text { 2. } & (1) \\
\text { 3. } & (2) \\
\text { 4. } & (1)\end{array}$ & $\begin{array}{l}\text { 1. } 50 \% \\
\text { 2. } 12.5 \% \\
\text { 3. } 25 \% \\
\text { 4. } 12.5 \%\end{array}$ & $\begin{array}{l}\text { 1. (2) } \\
\text { 2. (2) } \\
\text { 3. (1) } \\
\text { 4. (1) }\end{array}$ & $\begin{array}{l}\text { 1. } 33.3 \% \\
\text { 2. } 33.3 \% \\
\text { 3. } 16.7 \% \\
\text { 4. } 16.7 \%\end{array}$ \\
\hline
\end{tabular}

Article.5.2. Each Party shall take legislative, administrative or policy measures, as appropriate, with the aim of ensuring that benefits arising from the utilization of genetic resources that are held by indigenous and local communities, in accordance with domestic legislation regarding the established rights of these indigenous and local communities over these genetic resources, are shared in a fair and equitable way with the communities concerned, based on mutually agreed terms. [Comment: In this Clause, the rights of indigenous and local communities over genetic resources are recognized and upheld decisive in context of sharing of the benefits. However, this sharing is to be based on domestic legislation encompassing rights of indigenous \& local communities.]

Article.5.5. Each Party shall take legislative, administrative or policy measures, as appropriate, in order that the benefits arising from the utilization of traditional knowledge associated with genetic resources are shared in a fair and equitable way with indigenous and local communities holding such knowledge. Such sharing shall be upon mutually agreed terms. [Comment: This clause duly recognizes the rights of indigenous and local communities over their traditional knowledge associated with genetic resources. It also recognizes that the benefits should be shared with indigenous and local communities equitably.]

\begin{tabular}{|c|c|c|c|c|c|c|c|}
\hline $\begin{array}{l}\text { 4. Does this } \\
\text { Article.5.2 \& } \\
\text { Article.5.5 of Nagoya } \\
\text { Protocol bind the } \\
\text { Parties to take } \\
\text { essential legislative, } \\
\text { administrative or }\end{array}$ & $\begin{array}{l}\text { 1. Yes, this } \\
\text { section provides the } \\
\text { binding on Parties to } \\
\text { take legislative, } \\
\text { administrative or } \\
\text { policy measures. } \\
\text { 2. No, it lacks }\end{array}$ & $\begin{array}{ll}\text { 1. } & \text { (4) } \\
\text { 2. } & \text { (4) } \\
\text { 3. } & \text { (2) }\end{array}$ & $\begin{array}{ll}\text { 1. } & 40 \% \\
\text { 2. } & 40 \% \\
\text { 3. } & 20 \%\end{array}$ & $\begin{array}{ll}1 . & (\mathbf{4}) \\
2 . & (\mathbf{4}) \\
3 . & (\mathbf{0})\end{array}$ & $\begin{array}{ll}\text { 1. } & 50 \% \\
\text { 2. } & 50 \% \\
\text { 3. } & 0 \%\end{array}$ & $\begin{array}{ll}1 . & (3) \\
2 . & (3) \\
3 . & (\mathbf{0})\end{array}$ & $\begin{array}{ll}\text { 1. } & 50 \% \\
\text { 2. } & 50 \% \\
\text { 3. } & 0 \%\end{array}$ \\
\hline
\end{tabular}




\begin{tabular}{|c|c|c|c|c|c|c|c|}
\hline \multirow{2}{*}{$\begin{array}{c}\text { Questions of } \\
\text { Opinion Survey }\end{array}$} & \multirow{2}{*}{$\begin{array}{c}\text { Options of } \\
\text { Responses against } \\
\text { the Questions }\end{array}$} & \multicolumn{2}{|c|}{$\begin{array}{l}\text { Academic/Research } \\
\text { Institutions }(n=10)\end{array}$} & \multicolumn{2}{|c|}{$\begin{array}{c}\text { Civil Society } \\
\text { Organizations }(n=8)\end{array}$} & \multicolumn{2}{|c|}{$\begin{array}{c}\text { Concerned Individuals } \\
(\mathrm{n}=6)\end{array}$} \\
\hline & & \begin{tabular}{|c|} 
No. of \\
Response \\
\end{tabular} & Response \%age & \begin{tabular}{|c|} 
No. of \\
Response
\end{tabular} & Response \%age & $\begin{array}{c}\text { No. of } \\
\text { Response } \\
\end{array}$ & Response \%age \\
\hline $\begin{array}{l}\text { policy measures for } \\
\text { sharing benefits with } \\
\text { concerned ILCs in a } \\
\text { fair and equitable } \\
\text { way? }\end{array}$ & $\begin{array}{l}\text { clarity and binding } \\
\text { force. } \\
\text { 3. I cannot say. }\end{array}$ & & & & & & \\
\hline $\begin{array}{l}\text { 5. Do you think } \\
\text { that the Parties } \\
\text { would incorporate } \\
\text { adequately the } \\
\text { sharing of benefits } \\
\text { to concerned ILCs } \\
\text { into their respective } \\
\text { legislative, } \\
\text { administrative or } \\
\text { policy measures? }\end{array}$ & $\begin{array}{l}\text { 1. Yes, only some } \\
\text { Parties would make } \\
\text { the benefit sharing to } \\
\text { ILCs mandatory in } \\
\text { their legislative, } \\
\text { administrative or } \\
\text { policy measures. } \\
\text { 2. Yes, all Parties } \\
\text { would make the } \\
\text { benefit sharing to } \\
\text { ILCs mandatory in } \\
\text { their legislative, } \\
\text { administrative or } \\
\text { policy measures. } \\
\text { 3. Yes, all or } \\
\text { some Parties would } \\
\text { make the benefit } \\
\text { sharing to ILCs } \\
\text { mandatory in their } \\
\text { legislative, } \\
\text { administrative or } \\
\text { policy measures, but } \\
\text { with their bias against } \\
\text { indigenous people. } \\
\text { 4. Not at all, most } \\
\text { of the governments } \\
\text { neglect their } \\
\text { respective ILCs. } \\
5 . \quad \text { I cannot say. }\end{array}$ & $\begin{array}{ll}1 . & (\mathbf{5}) \\
2 . & (\mathbf{1}) \\
3 . & (\mathbf{1}) \\
4 . & (\mathbf{3}) \\
5 . & \mathbf{( 0 )}\end{array}$ & $\begin{array}{ll}\text { 1. } & 50 \% \\
\text { 2. } & 10 \% \\
\text { 3. } & 10 \% \\
\text { 4. } & 30 \% \\
5 . & 0 \%\end{array}$ & $\begin{array}{ll}1 . & (2) \\
2 . & (2) \\
3 . & (2) \\
4 . & (2) \\
5 . & (0)\end{array}$ & $\begin{array}{ll}\text { 1. } & 25 \% \\
\text { 2. } & 25 \% \\
\text { 3. } & 25 \% \\
\text { 4. } & 25 \% \\
5 . & 0 \%\end{array}$ & $\begin{array}{ll}\text { 1. } & (\mathbf{2}) \\
2 . & (\mathbf{1}) \\
3 . & (\mathbf{2}) \\
4 . & (\mathbf{1}) \\
5 . & \mathbf{( 0 )}\end{array}$ & $\begin{array}{ll}\text { 1. } & 33.3 \% \\
\text { 2. } & 16.7 \% \\
\text { 3. } & 33.3 \% \\
\text { 4. } & 16.7 \% \\
5 . & 0 \%\end{array}$ \\
\hline $\begin{array}{l}\text { 6. Is there any } \\
\text { obligation on Parties, } \\
\text { under Nagoya } \\
\text { Protocol, to invite } \\
\text { participation of their } \\
\text { ILCs in the process of } \\
\text { creating/ formulating/ } \\
\text { changing of their } \\
\text { legislations, rules, } \\
\text { regulations, policies, } \\
\text { guidelines, etc. } \\
\text { guaranteeing the } \\
\text { sharing of benefits to } \\
\text { ILCs? }\end{array}$ & $\begin{array}{l}\text { 1. Yes, the } \\
\text { Nagoya Protocol } \\
\text { provides an } \\
\text { obligation on } \\
\text { Parities to invite } \\
\text { participation of } \\
\text { their ILCs. } \\
2 . \quad \text { No, the } \\
\text { Nagoya Protocol } \\
\text { does not provide } \\
\text { any obligation on } \\
\text { Parties. } \\
3 . \quad \text { I cannot say. }\end{array}$ & $\begin{array}{ll}\text { 1. } & (5) \\
\text { 2. } & (3) \\
\text { 3. } & (2)\end{array}$ & $\begin{array}{ll}\text { 1. } & 50 \% \\
\text { 2. } & 30 \% \\
\text { 3. } & 20 \%\end{array}$ & $\begin{array}{ll}\text { 1. } & (\mathbf{4}) \\
\text { 2. } & (\mathbf{3}) \\
\text { 3. } & \mathbf{( 1 )}\end{array}$ & $\begin{array}{ll}\text { 1. } & 50 \% \\
\text { 2. } & 37.5 \% \\
\text { 3. } & 12.5 \%\end{array}$ & $\begin{array}{ll}\text { 1. } & \mathbf{( 3 )} \\
\text { 2. } & \mathbf{( 3 )} \\
\text { 3. } & \mathbf{( 0 )}\end{array}$ & $\begin{array}{ll}\text { 1. } & 50 \% \\
\text { 2. } & 50 \% \\
\text { 3. } & 0 \%\end{array}$ \\
\hline $\begin{array}{l}\text { 7. Considering the } \\
\text { fact that most Parties } \\
\text { do not truly respect, } \\
\text { recognize and enforce }\end{array}$ & $\begin{array}{l}\text { 1. Yes, only } \\
\text { some provider } \\
\text { countries would } \\
\text { percolate the }\end{array}$ & $\begin{array}{ll}\text { 1. } & (\mathbf{6}) \\
\text { 2. } & (\mathbf{1}) \\
\text { 3. } & (\mathbf{1}) \\
\text { 4. } & (\mathbf{2}) \\
\end{array}$ & $\begin{array}{ll}\text { 1. } & 60 \% \\
\text { 2. } & 10 \% \\
\text { 3. } & 10 \% \\
\text { 4. } & 20 \% \\
\end{array}$ & $\begin{array}{ll}\text { 1. } & (\mathbf{4}) \\
\text { 2. } & (2) \\
\text { 3. } & (\mathbf{0 )} \\
\text { 4. } & (2) \\
\end{array}$ & $\begin{array}{ll}\text { 1. } & 50 \% \\
\text { 2. } & 25 \% \\
\text { 3. } & 0 \% \\
\text { 4. } & 25 \% \\
\end{array}$ & $\begin{array}{ll}\text { 1. } & (\mathbf{0}) \\
\text { 2. } & (\mathbf{0}) \\
\text { 3. } & (\mathbf{2}) \\
\text { 4. } & (\mathbf{4})\end{array}$ & $\begin{array}{ll}\text { 1. } & 0 \% \\
\text { 2. } & 0 \% \\
\text { 3. } & 33.3 \% \\
\text { 4. } & 66.7 \% \\
\end{array}$ \\
\hline
\end{tabular}




\begin{tabular}{|c|c|c|c|c|c|c|c|}
\hline \multirow{2}{*}{$\begin{array}{c}\text { Questions of } \\
\text { Opinion Survey }\end{array}$} & \multirow{2}{*}{$\begin{array}{c}\text { Options of } \\
\text { Responses against } \\
\text { the Questions }\end{array}$} & \multicolumn{2}{|c|}{$\begin{array}{l}\text { Academic/Research } \\
\text { Institutions }(n=10)\end{array}$} & \multicolumn{2}{|c|}{$\begin{array}{c}\text { Civil Society } \\
\text { Organizations }(n=8)\end{array}$} & \multicolumn{2}{|c|}{$\begin{array}{c}\text { Concerned Individuals } \\
(\mathrm{n}=6)\end{array}$} \\
\hline & & $\begin{array}{c}\text { No. of } \\
\text { Response }\end{array}$ & Response \%age & \begin{tabular}{|c|} 
No. of \\
Response
\end{tabular} & Response \%age & $\begin{array}{c}\text { No. of } \\
\text { Response }\end{array}$ & Response \%age \\
\hline $\begin{array}{l}\text { the rights of their } \\
\text { own indigenous } \\
\text { people, will the } \\
\text { benefits received by } \\
\text { provider Parties be } \\
\text { further shared with } \\
\text { their respective ILCs } \\
\text { holding the } \\
\text { accessed/utilized } \\
\text { genetic resource or } \\
\text { associated ITK? }\end{array}$ & $\begin{array}{l}\text { benefits to their } \\
\text { concerned ILCs in } \\
\text { due quantum. } \\
2 . \quad \text { Yes, all } \\
\text { provider countries } \\
\text { would percolate the } \\
\text { benefits to their } \\
\text { concerned ILCs in } \\
\text { due quantum. } \\
3 \text {. Yes, all or } \\
\text { some provider } \\
\text { countries would } \\
\text { percolate the } \\
\text { benefits to their } \\
\text { concerned ILCs, but } \\
\text { a little. } \\
4 . \quad \text { No, I doubt if } \\
\text { any benefit would } \\
\text { percolate to ILCs. } \\
5 . \quad \text { I don't know. }\end{array}$ & \begin{tabular}{|ll}
5. & $(0)$ \\
\end{tabular} & 5. $0 \%$ & 5. $\quad(\mathbf{0})$ & 5. $0 \%$ & 5. (0) & 5. $0 \%$ \\
\hline $\begin{array}{l}8 . \text { How would the } \\
\text { benefits be shared by } \\
\text { provider Parties } \\
\text { (usually developing } \\
\text { countries) with } \\
\text { indigenous people } \\
\text { and/or local } \\
\text { communities holding } \\
\text { the genetic resource } \\
\text { or associated ITK } \\
\text { being accessed/ } \\
\text { utilized? }\end{array}$ & $\begin{array}{l}\text { 1. I have no } \\
\text { idea. } \\
\text { 2. This depends } \\
\text { on the Parties how } \\
\text { they develop a } \\
\text { mechanism and } \\
\text { what mechanism } \\
\text { they develop. } \\
\text { 3. I suggest the } \\
\text { following } \\
\text { mechanism: } \\
\text { (suggestions listed } \\
\text { below) }\end{array}$ & $\begin{array}{ll}\text { 1. } & (2) \\
\text { 2. } & (6) \\
3 . & (2)\end{array}$ & $\begin{array}{ll}\text { 1. } & 20 \% \\
\text { 2. } & 60 \% \\
\text { 3. } & 20 \%\end{array}$ & $\begin{array}{ll}\text { 1. } & \mathbf{( 3 )} \\
\text { 2. } & \mathbf{( 3 )} \\
\text { 3. } & (\mathbf{2})\end{array}$ & $\begin{array}{ll}\text { 1. } & 37.5 \% \\
\text { 2. } & 37.5 \% \\
\text { 3. } & 25 \%\end{array}$ & $\begin{array}{ll}\text { 1. } & (\mathbf{1}) \\
\text { 2. } & (3) \\
3 . & (2)\end{array}$ & $\begin{array}{ll}\text { 1. } & 16.7 \% \\
\text { 2. } & 50 \% \\
\text { 3. } & 33.3 \%\end{array}$ \\
\hline $\begin{array}{l}\text { 9. What do you } \\
\text { understand from the } \\
\text { phrase "domestic } \\
\text { legislation regarding } \\
\text { the established rights } \\
\text { of these indigenous } \\
\text { and local } \\
\text { communities over } \\
\text { these genetic } \\
\text { resources" in above } \\
\text { Article.5.2 of } \\
\text { Nagoya Protocol? }\end{array}$ & $\begin{array}{l}\text { 1. I cannot } \\
\text { understand it. } \\
\text { 2. My } \\
\text { interpretation of the } \\
\text { phrase is as under: } \\
\text { (interpretations } \\
\text { listed below) }\end{array}$ & \begin{tabular}{|ll}
1. & $(2)$ \\
2. & $(8)$
\end{tabular} & $\begin{array}{ll}\text { 1. } & 20 \% \\
\text { 2. } & 80 \%\end{array}$ & $\begin{array}{ll}1 . & (1) \\
2 . & (7)\end{array}$ & $\begin{array}{ll}\text { 1. } & 12.5 \% \\
\text { 2. } & 87.5 \%\end{array}$ & 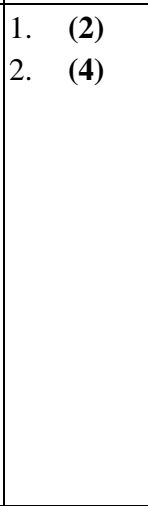 & $\begin{array}{ll}\text { 1. } & 33.3 \% \\
\text { 2. } & 66.7 \% \\
\end{array}$ \\
\hline
\end{tabular}


Table 2. Fair and Equitable Sharing of Benefits: Opinions of CBD/NP Parties [position of countries represents that of 2014]

\begin{tabular}{|c|c|c|c|c|c|c|c|c|c|c|c|c|c|c|c|}
\hline \multirow{3}{*}{$\begin{array}{l}\text { Q. } \\
\text { No. }\end{array}$} & \multirow{3}{*}{ Questions of Opinion Survey } & \multirow{3}{*}{ Response Options } & \multirow{3}{*}{$\begin{array}{l}\text { \%age of } \\
\text { Countries' } \\
\text { Response }\end{array}$} & \multicolumn{12}{|c|}{ Responses of Countries } \\
\hline & & & & \multicolumn{3}{|c|}{ South Asia } & \multicolumn{3}{|c|}{$\begin{array}{c}\text { South East } \\
\text { Asia (North } \\
\text { Block) }\end{array}$} & \multicolumn{3}{|c|}{\begin{tabular}{|c|} 
South East \\
Asia (South \\
Block)
\end{tabular}} & \multicolumn{3}{|c|}{$\begin{array}{c}\text { North } \\
\text { Asia }\end{array}$} \\
\hline & & & & I & $\mathbf{N}$ & Bd & Th & $\mathbf{L}$ & $\mathbf{V}$ & $\mathbf{P}$ & $\mathbf{B r}$ & $\mathbf{T i}$ & M & & \\
\hline 1. & $\begin{array}{l}\text { Is there recognition of ILCs in } \\
\text { national ABS policy/law over users' } \\
\text { access to genetic resources and } \\
\text { traditional knowledge, and over } \\
\text { sharing of benefits arising out of } \\
\text { utilization of genetic resources? }\end{array}$ & $\begin{array}{l}\text { 1. Yes, to large extent. } \\
\text { 2. Yes, to some extent. } \\
\text { 3. No, not at all. } \\
\text { 4. I do not know. }\end{array}$ & $\begin{array}{l}\text { 1. } 40.00 \% \\
\text { 2. } 20.00 \% \\
3.30 .00 \% \\
4.10 .00 \% \\
\text { NAt }=1 \\
\text { NAp }=1\end{array}$ & 1 & NAp & 2 & 4 & 3 & 1 & 1 & \begin{tabular}{|c|c|}
3 \\
\end{tabular} & NAt & 3 & 1 & \\
\hline 2. & $\begin{array}{l}\text { Whether or not the indigenous and } \\
\text { local communities (ILCs) were/are } \\
\text { allowed taking part in national ABS } \\
\text { law/policy making? }\end{array}$ & $\begin{array}{l}\text { 1. Yes, to large extent. } \\
\text { 2. Yes, to some extent. } \\
\text { 3. No, not at all. } \\
\text { 4. I do not know. }\end{array}$ & $\begin{array}{l}1.18 .18 \% \\
2.36 .36 \% \\
3.18 .18 \% \\
4.27 .27 \% \\
\text { NAt }=1 \\
\end{array}$ & 1 & 4 & 4 & 2 & 2 & 2 & 1 & 2 & NAt & 3 & 44 & \\
\hline 3. & $\begin{array}{l}\text { Was/is ILCs' participation active or } \\
\text { passive? }\end{array}$ & $\begin{array}{l}\text { 1. Active participation } \\
\text { 2. Passive participation } \\
\text { 3. No participation } \\
\text { 4. I do not know }\end{array}$ & $\begin{array}{l}\text { 1. } 30.00 \% \\
\text { 2. } 30.00 \% \\
\text { 3. } 20.00 \% \\
\text { 4. } 20.00 \% \\
\text { NAt }=1 \\
\text { NAp }=1\end{array}$ & 1 & NAp & 4 & 2 & 2 & 2 & 1 & 1 & NAt & 3 & 4 & \\
\hline 4. & $\begin{array}{l}\text { Were/are the concerns, voices or } \\
\text { viewpoints of ILCs respected, } \\
\text { integrated or incorporated in the } \\
\text { national ABS policy/law? }\end{array}$ & $\begin{array}{l}\text { 1. Yes, to large extent. } \\
\text { 2. Yes, to some extent. } \\
\text { 3. No, not at all. } \\
\text { 4. I do not know. }\end{array}$ & $\begin{array}{l}\text { 1. } 20.00 \% \\
\text { 2. } 60.00 \% \\
\text { 3. } 20.00 \% \\
\text { 4. } 00.00 \% \\
\text { NAt }=1 \\
\text { NAp }=1 \\
\end{array}$ & 1 & NAp & 2 & 2 & 2 & 2 & 2 & 1 & NAt & 3 & 2 & \\
\hline 5. & $\begin{array}{l}\text { As envisaged in Article. } 5.2 \& \\
\text { Article.5.5 of Nagoya Protocol, does } \\
\text { your country's ABS } \\
\text { legislation/policy provide for } \\
\text { sharing benefits with concerned } \\
\text { ILCs in a fair and equitable way? }\end{array}$ & $\begin{array}{l}\text { 1. Yes, our country's } \\
\text { ABS law/policy } \\
\text { provides for sharing } \\
\text { benefits with } \\
\text { concerned ILCs in a } \\
\text { fair and equitable } \\
\text { way. } \\
\text { 2. Yes, our country's } \\
\text { ABS law/policy } \\
\text { provides for sharing } \\
\text { benefits with } \\
\text { concerned ILCs, but } \\
\text { not in a fair and } \\
\text { equitable way. } \\
\text { 3. No, our country's } \\
\text { ABS law/policy does } \\
\text { not provide for } \\
\text { sharing benefits with } \\
\text { concerned ILCs in a } \\
\text { fair and equitable } \\
\text { way. } \\
\text { 4. I cannot say. }\end{array}$ & $\begin{array}{l}\text { 1. } 20.00 \% \\
\text { 2. } 10.00 \% \\
\text { 3. } 30.00 \% \\
\text { 4. } 40.00 \% \\
\text { NAt }=1 \\
\text { NAp }=1\end{array}$ & 1 & NAp & 4 & 4 & 4 & 2 & 1 & 4 & NAt & 3 & 3 & \\
\hline 6. & $\begin{array}{l}\text { How would the benefits received by } \\
\text { your country further be shared with } \\
\text { your indigenous people and/or local } \\
\text { communities holding the genetic } \\
\text { resource or associated ITK being } \\
\text { accessed/ utilized? }\end{array}$ & $\begin{array}{l}\text { 1. I cannot say. } \\
\text { 2. Our country has no } \\
\text { clues about } \\
\text { developing any such } \\
\text { mechanism. } \\
\text { 3. I suggest the } \\
\text { following } \\
\text { mechanism: }\end{array}$ & $\begin{array}{l}\text { 1. } 30.00 \% \\
\text { 2. } 30.00 \% \\
\text { 3. } 40.00 \% \\
\text { NAt }=1 \\
\text { NAp }=1\end{array}$ & $3 *$ & NAp & 2 & 2 & 1 & $3 *$ & $3 *$ & 3 & NAt & 2 & 1 & \\
\hline
\end{tabular}

NAt $=$ Not Attempted; NAp $=$ Not Applicable.

$\mathrm{I}=$ India $; \mathrm{N}=$ Nepal; $\mathrm{Bd}=$ Bangladesh Th = Thailand L = Lao; V = Vietnam; $\mathrm{P}=$ Philippines $; \mathrm{Br}=\mathrm{Brunei}$; Ti = Timor; $\mathrm{M}=$ Mongolia $; \mathrm{R}=$ Russia $; \mathrm{C}=$ China 


\subsection{Participant Observation}

Another research tool used in this study is participant observation of the negotiation processes within the CBD's global forums. Participant observation is a research technique used for qualitative research purposes (Kawulich, 2005). DeMunck and Sobo (1998) describe participant observation as the primary method used by anthropologists doing fieldwork, which involves "active looking, improving memory, informal interviewing, writing detailed field notes, and [....] patience" (quoted in: DeWalt \& DeWalt, 2002, p.vii). The first author directly observed the following two international meetings on the ABS regime:

- The Second Meeting of the Open-Ended Ad Hoc Intergovernmental Committee for the Nagoya Protocol on ABS (ICNP-2) (9 - 13 April 2012, New Delhi, India)

- The Eleventh Meeting of the Conference of the Parties (COP11) to the Convention on Biological Diversity (8 19 October 2012, Hyderabad, India)

The first author observed and interacted with the delegates of various countries mentioned in Annex I. He also took part in COP11 negotiation meetings and side events, as well as meetings of ILCs, NGOs and international organizations, and open shows organized by ILCs. Some of the respondents with whom the first author interacted were members of CNAs of their respective countries. They came to attend the meetings that took place on ABS mechanisms and outstanding Nagoya Protocol issues.

\section{Results and Discussion}

Article 1 of the Nagoya Protocol states that its objective is "the fair and equitable sharing of the benefits arising from the utilization of genetic resources, including appropriate access to genetic resources and appropriate transfer of relevant technologies, taking into account all the rights over those resources and technologies, and by appropriate funding, thereby contributing to the conservation of biological diversity and the sustainable use of its components" (see also: Morgera, Tsioumani \& Buck, 2014; Morgera, Buck \& Tsioumani, 2012; Frein \& Meyer, 2011). Article $5.1^{3}$ of the Nagoya Protocol clearly describes the obligations pertaining to the fair and equitable sharing of the benefits arising out of the utilization of genetic resources. According to Frein and Meyer (2011), Article 5.1 of Nagoya Protocol provides that the benefits to be shared are not only those arising from the research and development phase (defined as "utilization") but also from "subsequent applications and commercialization". This provision guarantees that the main phase of benefit creation based on the utilization of genetic resources - the commercialization phase - is covered by ABS agreements. Moreover, in connection with Article 2 of Nagoya Protocol, the benefits arising from the utilization of the biochemical compounds derived from the accessed genetic resource may also fall under the scope of ABS agreements (Frein \& Meyer, 2011). To elaborate the nature of benefit-sharing, the Annex to the Nagoya Protocol contains a non-exclusive list of ten monetary and 17 non-monetary benefits that could be included in MAT.

Frein and Meyer (2011) further stress that the Nagoya Protocol sets new international standards on access and benefit-sharing and opens a window for the implementation of the United Nations Declaration on the Rights of Indigenous Peoples (UNDRIP) through Article 5.2 and Article 5.5 $5^{5}$ of Nagoya Protocol. While Article 8(j) and 10(c) of the CBD both address ILCs and the concept of benefit-sharing was included as a matter of justice between developed and developing countries, the Nagoya Protocol deepens these commitments. According to Frein and Meyer (2011), while it is the UNDRIP that establishes the international standard on the rights of Indigenous peoples over their genetic resources and ATK, the Nagoya Protocol also obliges its Parties to ensure through national rules that prior informed consent (PIC) is sought by users, and that benefits are shared based on MAT, where ILCs have ownership rights over genetic resources. Otherwise, the State is free to determine rules on access to genetic resources at its discretion, in keeping with the CBD (Frein \& Meyer, 2011).

3 Article 5.1 of the Nagoya Protocol reads: "In accordance with Article 15, paragraphs 3 and 7 of the Convention, benefits arising from the utilization of genetic resources as well as subsequent applications and commercialization shall be shared in a fair and equitable way with the Party providing such resources, that is the country of origin of such resources or a Party that has acquired the genetic resources in accordance with the Convention. Such sharing shall be upon mutually agreed terms."

4 Article 5.2 of the Nagoya Protocol reads: "Each Party shall take legislative, administrative or policy measures, as appropriate, with the aim of ensuring that benefits arising from the utilization of genetic resources that are held by indigenous and local communities, in accordance with domestic legislation regarding the established rights of these indigenous and local communities over these genetic resources, are shared in a fair and equitable way with the communities concerned, based on mutually agreed terms."

5 Article 5.5 of the Nagoya Protocol reads: "Each Party shall take legislative, administrative or policy measures, as appropriate, in order that the benefits arising from the utilization of traditional knowledge associated with genetic resources are shared in a fair and equitable way with indigenous and local communities holding such knowledge. Such sharing shall be upon mutually agreed terms." 
In Article 5.2 of the Nagoya Protocol, the rights of ILCs over genetic resources are recognized and affirmed in the context of benefit-sharing. However, this sharing is to be based on domestic legislation encompassing rights of ILCs. Article 5.5 duly recognizes the rights ILCs over their traditional knowledge associated with genetic resources and provides that benefits should be shared fairly and equitably with ILCs when ATK is accessed, based on MAT.

This opinion survey analyses the implications of benefit-sharing from several critical angles. The following sections are based on the responses of interviewees, participant observations, and literature review.

\subsection{Benefit-Sharing with Provider Parties in a Fair and Equitable Way}

Conforming to the CBD's third objective related to ABS, many developing country Parties (usually the providers of genetic resources) have enacted new legislation or regulations, or have modified existing ones, in order to accommodate ABS matters. For example, with the Executive Order $247^{6}$ (EO 247), establishing a framework for access to genetic resources, which entered into force on May 18, 1995, the Philippines enacted the first ABS law globally (Medaglia, Perron-Welch \& Phillips, 2014). However, EO 247 principally addressed bioprospecting; later, benefit-sharing clauses were incorporated into the new Wildlife $\mathrm{Act}^{7}$ of the Philippines. Similarly, Vietnam enacted Biodiversity Law No. 20/2008/QH12 ${ }^{8}$ and made provisions for access to genetic resources and benefit-sharing under its Articles 58 and 61.

Yet, the responsibility of benefit-sharing with providers in a fair and equitable way lies largely with the user countries. The compliance obligations of the Nagoya Protocol require Parties to support the legislation of other Parties, including MAT. In this sense, Parties do have obligations to address benefit-sharing. In developed countries, however, legislation encompassing benefit-sharing with provider countries is often weak. For example, some European countries have ABS-related instruments in place already, but such laws do not include provisions guaranteeing benefit-sharing. Denmark, for instance, adopted an ABS Act, but it contains no provisions ensuring that benefits are truly shared with providers. Moreover, the Danish ABS Act also excludes benefit-sharing for the utilization of traditional knowledge. Similarly, in Greece, access to genetic resources is subject to a permit delivered by the CNAs, but these permits do not contain benefit-sharing provisions, whether for utilization of, or trade in, genetic resources (Coolsaet, 2015, p.374). Likewise, the Norwegian Nature Diversity Act, 2009 (Act No. 100) only includes the possibility of benefit-sharing for the utilization of Norwegian genetic resources, without making it mandatory; it does not include benefit sharing clauses if Norway utilizes genetic resources accessed from elsewhere (Coolsaet, 2015, p.374). As a result, the lack of measures adopting equitable benefit-sharing rules by user countries in Europe has resulted in restrictive conditions for access to genetic resources and/or traditional knowledge in provider countries (generally developing nations). According to Prip and Rosendal (2015), the restrictive conditions for access to genetic resources imposed by some countries can be explained as a reaction to the reluctance of developed countries to adopt user-country measures to support effective benefit-sharing and compliance in provider countries (Morgera, Buck \& Tsioumani, 2013). The European Commission itself acknowledges that the resulting difficulties in accessing global genetic resources may strongly affect the activities of European economic and environmental stakeholders, including botanic gardens, culture collections, gene banks, academic research institutions, biotechnology companies and the food and beverages industry (Coolsaet, 2015, p.373).

To investigate the implications of the requirement found in Article 5.1 of Nagoya Protocol, the academic/research institutions, CSOs and individuals were asked, "Do you think that the user Parties (generally developed countries) would share the benefits appropriately to provider Parties (usually developing countries)?" (Table 1: q.1). A majority $(60 \%)$ of responding academic/ research institutions confirmed that the benefits would be shared by all or some user countries, but they showed doubts if those benefits would be shared in a fair and equitable way (Table 1: q.1). Nearly one-third (30\%) of responding academic/research institutions did not believe that benefits would be appropriately shared in a fair and equitable way by all users (Table 1: q.1). A minority (10\%) of academic/research institutions responded that the benefits would indeed be appropriately shared in a fair and equitable way by some user countries (Table 1: q.1). The majority of CSOs surveyed (62.5\%) confirmed that benefits would be shared by all or some user countries, but they showed doubts as to whether those benefits would be shared in a fair and equitable way (Table 1: q.1). $12.5 \%$ responded that the benefits would be appropriately shared in a fair and equitable way by some user countries;

6 Executive Order No. 247, Prescribing Guidelines and Establishing a Regulatory Framework for the Prospecting of Biological and Genetic Resources, Their By-Products and Derivatives, for Scientific and Commercial Purposes, and for Other Purposes, (1995), available online: http://www.wipo.int/wipolex/en/text.jsp?file_id=225249. This law implemented CBD commitments on ABS.

7 Philippines Republic Act No. 9147, Wildlife Resources Conservation and Protection Act, enacted July 30, 2001, available online: http://faolex.fao.org/docs/texts/phi41009.doc. This also implemented CBD commitments and are regulated by the Joint DENR-DA-PCSD-NCIP Administrative Order No. 1 of 2005 prescribing Guidelines for Bioprospecting Activities in the Philippines.

8 Regulations adopted in 2017 the Decree on the Management of Access to Genetic Resources and the Sharing of Benefits Arising from their Utilization, available on: https://absch.cbd.int/database/record/ABSCH-MSR-VN-237595 
12.5\% said that benefits would be appropriately shared in a fair and equitable way by all user countries (Table 1: q.1); and $12.5 \%$ asserted that benefits would not be appropriately shared in a fair and equitable way by all users (Table 1: q.1). On the same question, a majority of surveyed individuals (66.6\%) asserted that benefits would be shared by all or some user countries, but they showed doubts as to whether those benefits would be shared in a fair and equitable way (Table 1: q.1). $16.7 \%$ did not agree that the benefits would be appropriately shared in a fair and equitable way by all users (Table 1: q.1), and another $16.7 \%$ asserted that the benefits would be appropriately shared in a fair and equitable way by all users (Table 1: q.1). An analysis of these responses leads to the inference that the benefits arising from the utilization of genetic resources may not generally be shared in a fair and equitable way. It also refutes the intended effectiveness of Nagoya Protocol, and suggests that access to, and use of, genetic resources by the user Parties (generally developed nations) may not fully adhere to Article 5.1.

Some of the respondents highlighted that the Nagoya Protocol will only be considered effective once it ensures international legal provisions and financial support for the "voiceless" Indigenous communities of the South who possess valuable knowledge of local biodiversity and its uses. Other respondents articulated that, considering the existing power imbalances, it is not certain that the fair sharing of benefits will happen. Since the mechanism of benefit-sharing is subject to negotiation between governments, fair and equitable sharing depends on the trade relations of the negotiating nations and their relative strength on economic and ecological fronts. One respondent, however, noted that in general it is not the user Party that shares the benefits but the actual user (a public body or private entity). In some cases, involving the utilization of a genetic resource or associated TK, the recipient of the benefit-sharing will not be the Party but, to a greater or lesser extent, the holder(s) of the genetic resource or associated TK. Nevertheless, if the holder of the genetic resource or associated TK is an Indigenous community, for example, the negotiations are usually done by the government, often without the knowledge of the community in question. Yet, the Nagoya Protocol deals with four entities, not with two: the provider Party, the user Party, the actual provider, and the actual user. Ideally, all of them have certain rights and obligations as provided by the Nagoya Protocol, the CBD, and the UNDRIP at the international level, and through domestic ABS legislation if it exists.

\subsection{Integration of Justice and Equity by Users in the Preparation of MAT}

Access to genetic resources in the contemporary era can result in sizable commercial returns. Users, often based in developed countries, may exercise power and unfair means to acquire and control genetic resources and associated TK, as the user and provider are not on equal footing in the negotiations. With a view to avoiding the exploitation of providers, the principles of natural justice should be applied, partly out of precaution. Similarly, the principle of equity should be applied to protect the personal liberty and fundamental rights of individuals or groups. Therefore, incorporation of justice and equity concerns is crucial when preparing the MAT before accessing genetic resources and ATK.

The idea of MAT has been encouraged since the CBD came into existence as a way to ensure "fairness and equity" (Robinson, 2015). However, power asymmetries between the two negotiating parties to the MAT are believed to have a negative impact on justice and equity. Robinson (2015, p.193) has noted the existence of a range of providers with varying negotiation capabilities. Indigenous communities are observed to be in the weakest negotiating position; governments are more likely to make informed decisions as they have appropriate legal expertise and knowledge of ABS. However, Robinson (2015) has noted limited capacities in governmental departments within certain countries (such as Madagascar, Morocco, Samoa, Papua New Guinea, and Panama) in the area of ABS. This lack of capacity is frequently coupled with political bias, corruption, lack of familiarity with ABS, and education level. In addition, communities have reported lacking even minimum capacities and knowledge of ABS, thereby affecting their ability to negotiate a fair and equitable MAT (also see, Robinson, 2015, p.193). Therefore, both the providers and users, especially the governments and the users, need to carefully integrate justice and equity concerns at the time of preparing bilateral or multilateral agreement before accessing genetic resources or associated TK.

The Nagoya Protocol also addresses MAT between Parties. While Parties normally develop MAT during the negotiation of access to, or utilization of, genetic resources or TK, there is uncertainty as to whether justice and equity concerns are adequately addressed in MAT preparations. To understand the implications of this uncertainty, the question posed to the academic/research institutions was: "Will the user Parties (usually developed nations) take into account the justice and equity concerns during preparation of MAT before granting access to a genetic resource held by provider Parties (usually developing countries)?" (Table 1: q.2). The majority of academic/research institutions (40\%) opined that no user Parties would incorporate justice and equity concerns during preparation of MAT; while 30\% of academic/research institutions said that only some user Parties would incorporate justice and equity concerns, with reservations, during preparation of MAT (Table 1: q.2). Yet, $20 \%$ of academic/research institutions said that only some user Parties would incorporate justice and equity concerns without reservations during preparation of MAT. The CSOs were also posed the same question. Only one respondent (12.5\%) of those surveyed) opined that no user Parties would incorporate justice 
and equity concerns during preparation of MAT, while the majority of CSOs (37.5\%) said that only some user Parties would incorporate justice and equity concerns, with reservations, during the preparation of MAT (Table 1: q.2). A fraction (12.5\%) of surveyed CSOs confirmed that only some user Parties would incorporate justice and equity concerns without reservations during the preparation of MAT; and the same percentage of surveyed CSOs indicated that all user Parties would incorporate justice and equity concerns with reservations (Table 1: q.2). At the same time, one respondent CSO (12.5\%) was of the opinion that all user Parties would incorporate justice and equity concerns without reservations (Table 1: q.2). Further, the majority of the concerned individuals surveyed (50\%) expressed their opinion that only some user Parties would incorporate justice and equity concerns with reservations during preparation of MAT (Table 1: q.2), while one respondent (16.7\%) opined that all user Parties would incorporate justice and equity concerns with reservations (Table 1: q.2).

The above analysis of academic/research institutions and CSOs indicates that the possibilities of justice and equity concerns being incorporated during preparation of MAT are remote. Similarly, those individuals surveyed also highlighted the limited possibilities for justice and equity concerns to be incorporated during the preparation of MAT. It, therefore, seems that the existing neoliberal framework works primarily on the basis of market principles, while the question of justice and equity is minimized. MAT will definitely be prepared, but with no guarantee that justice and equity concerns will be taken into account.

While questioning justice and equity, a respondent explained that it is not the user Parties that prepare MATs, but the actual users in each case. Moreover, MAT is a contract that is negotiated between providers and users (and is not unilaterally prepared by the users only). Thus, incorporation of justice and equity concerns depends on both sides. If a contract does not seem to be equitable and just, the providers need not to sign it. However, in the preceding section 3.1, we have observed that the power asymmetry between two negotiating nations or between user and provider can restrain the fair and equitable sharing of benefits. The same observation can also be applied here; the incorporation of justice and equity concerns being incorporated or not surely depends on the power equation, as well as the trade needs of the two sides. Countries and users owning resources, technologies and strategic positions in global trade usually possess bargaining power. So, the conduct of such countries needs to be seen from perspectives of their adoption of fair, equitable and just dealings during negotiations of MAT before accessing the genetic resources or associated TK from developing or poor nations/communities.

\subsection{Development of MAT between Parties on Equity Principles}

The principles of equity, which should be incorporated in developing MAT, are explained in preceding section 3.2. However, the capacity of governments, Indigenous groups and in situ bioresource holders must be linked with the embeddedness of equity principles in developing the bilateral or multilateral agreements. In its preamble, the Nagoya Protocol recognizes the "importance of promoting equity and fairness in negotiation of mutually agreed terms (MAT) between providers and users of genetic resources". In light of the preamble, with the objective of evaluating the position of provider Parties concerning equity in the development of MAT before accessing genetic resources, the academic/research institutions were asked whether developing countries should be able to draft the MAT on equity principles, as opposed to the bargaining positions of user countries (usually developed nations) (Table 1: q.3). A majority $(60 \%)$ of academic/research institutions surveyed responded that only some developing countries might have capacities to draft MAT on equity principles (Table 1: q.3). A number of respondents (30\%) from the academic/research institutions surveyed stated that the developing countries might have capacities to draft MAT, but not based on equity principles (Table 1: q.3). The same question was posed to CSOs, who responded somewhat differently from academic/research institutions. Half $(50 \%)$ of CSOs surveyed answered that only some developing countries may have capacities to draft MAT on equity principles (Table 1: q.3), while one-fourth (25\%) clearly stated that developing countries might have no capacity to draft MAT on the basis of equity principles. Another $12.5 \%$ of CSOs stated that developing countries may have capacities to draft MAT, but not on equity principles (Table 1: q.3). One-third (33.3\%) of individuals surveyed responded that only some developing countries might have capacities to draft MAT on the basis of equity principles (Table 1: q.3). Another third (33\%) stated that developing countries might have capacities to draft MAT, but not on the basis of equity principles (Table 1: q.3). A fraction (16.7\%) of individual respondents stated that developing countries may have no capacities to draft MAT on the basis of equity principles (Table 1: q.3).

The majority of academic institutions indicated that developing nations lack adequate capacities to draft MAT based on the principles of equity, as did the CSOs and individuals surveyed. However, it is observed that only some countries have greater understanding and capacities on the subject of MAT preparations. As a result, there is a need to enhance capacity of both the concerned government authorities and the ILCs. Respondents also indicated that both the parties will draft the MAT based on their bargaining positions; whether the terms and conditions are just and equitable would be a matter of interpretation after the terms have been agreed. The bargaining positions of two negotiators determine the extent of equity and justice in the deals, and hence special call is required to ensure the equity principles are taken care of during the development of MAT. A respondent drew attention to the need to enhance the capacity of the Parties well in advance 
of the negotiations. Other respondents stated that this might be possible, but in many cases, a great deal of capacity building might be needed.

The above observation in relation to the development of MAT can be supported with the fact that the terms are generally not clearly described within the MAT itself, particularly from the perspective of equity. For example, this is the case with existing or evolving ABS legislation in Panama, Venezuela, Colombia, Peru, Brazil, and Costa Rica. Another example is Kenya, where very little detail is provided in the country's ABS legislation regarding the content of MAT (Medaglia, Perron-Welch \& Phillips, 2014). Only a few countries have integrated equity principles in the clauses guiding the development of MAT prior, including Costa Rica, Australia, and Uganda.

\subsection{Domestic Law-Making for Benefit Sharing}

State sovereignty is the prime determinant of the nature of domestic ABS laws existing or under formulation. As scholars have stated,

the Convention recognizes the states' sovereign right to exploit their own biological resources and that the authority to determine access to genetic resources rests within the national government and is subject to national legislation; if required by its legislation, access to genetic resources should be granted on mutually agreed terms (MAT) between the provider and the user. (Broggiato et al., 2015, p.5)

Some academics have cited an excessive emphasis on State sovereignty. According to Raustiala and Victor (2004) and Hufty (2001), the call for increased sovereign control over genetic resources was first used by developed countries to justify the expansion of intellectual property rights over these resources. To reap the benefits from this extended sovereignty, profits had to be generated, and the realization of these profits via intellectual property rights required the establishment of a market and a mechanism for intellectual property protection. The idea of genetic resources and traditional knowledge as a new source of economic prosperity thus appealed to developed and developing countries alike (Raustiala \& Victor, 2004; Hufty, 2001). That is the reason that the Convention on Biological Diversity, in condition of increased national sovereignty, also recognizes the need for intellectual property rights (Broggiato et al., 2015 , p.17). The analysis in the following paragraphs explores the implications of domestic ABS laws, policies or administrative measures in light of the Nagoya Protocol's binding nature.

The Article 5.2 and Article 5.5 of the Nagoya Protocol were analyzed by asking the academic/research institutions whether these articles bind the Parties to take essential legislative, administrative or policy measures for sharing benefits with concerned ILCs in a fair and equitable way. Four respondents (40\%) responded that these articles of the Nagoya Protocol are binding on Parties, requiring them to take legislative, administrative or policy measures (Table 1: q.4). Another $40 \%$ of academic/research institutions surveyed stated that the articles lack clarity and binding force (Table 1: q.4). The opinions of CSOs were also analyzed in respect of Article 5.2 and Article 5.5 of the Nagoya Protocol. Half of the CSOs surveyed (50\%) maintained that these articles lack clarity and binding force (Table 1: q.4). On the contrary, the other half $(50 \%)$ responded that these articles bind Parties to take legislative, administrative or policy measures (Table 1: q.4). Likewise, the responses of certain concerned individuals were also analyzed. Half (50\%) of the individuals surveyed responded that these articles of the Nagoya Protocol bind Parties to take legislative, administrative or policy measures (Table 1: q.4); while the other half (50\%) said the articles lack clarity and binding force (Table 1: q.4). The opinions of academic/research institutions, CSOs and individuals concerning Article 5.2 and Article 5.5 of Nagoya Protocol are contradictory. Hence, it can be concluded that Article 5.2 and Article 5.5 of the Nagoya Protocol would be partially effective in achieving their purpose. However, it should be noted that the respondents' opinions represent the situation of 2014, before the Nagoya Protocol came into force. As a result, the status of various countries that have taken legislative, administrative or policy measures in accordance with the Nagoya Protocol may have changed.

According to observations, out of 99 Parties and 32 other signatories $^{9}$, until mid-2018, 49 countries and the European Union have uploaded their domestic ABS legislation, policy or administrative measures on CBD's ABS Clearinghouse ${ }^{10}$. Of these 49 countries, $28 \mathrm{EU}$ member countries ${ }^{11}$ have adopted the EU legislation on ABS enacted in 2014, and $13^{12}$ of these 28 countries have also adopted their own ABS laws/policies. Among the other 21 nations that have created and submitted their ABS instruments to the ABS Clearinghouse are Albania, Belarus, Brazil, Burkina Faso, Burundi, Côte d'Ivoire, Dominican Republic, Ecuador, Ethiopia, Guatemala, India, Japan, Kenya, Malawi, Mexico, Norway, Peru, South Africa, Switzerland, Uganda and Vietnam. An additional 16 countries have developed or modified their ABS

9 https://www.cbd.int/abs/nagoya-protocol/signatories/default.shtml

10 cf. CBD, accessed on 25 August 2017: https://absch.cbd.int/search/nationalRecords?schema=measure

11 https://europa.eu/european-union/about-eu/countries/member-countries_en

12 Names of those 13 countries are: Bulgaria, Croatia, Denmark, Finland, Germany, Hungary, Malta, Netherlands, Portugal, Slovakia, Spain, Sweden, UK. 
instruments but have not submitted them to the ABS Clearinghouse. These countries included Australia, Bolivia, Namibia, Seychelles, Mozambique, Malaysia, Philippines, Argentina, Guyana, Bangladesh, Bhutan, Nepal, Pakistan, Costa Rica, Nicaragua and Cuba. In addition to these 65 countries, many other countries have developed their ABS policies or strategies based on existing non-ABS laws such as patent laws, wildlife laws, agriculture laws, and so on. Examples of these countries include Egypt, Zambia, Iraq, Syria, Jordan, Botswana, Lesotho, Gambia, Zimbabwe, Afghanistan, Micronesia, Romania, Canada, China, Russia, Papua New Guinea, Niue, Vanuatu, Suriname, Venezuela, Panama, New Zealand, Solomon Islands, Cameroon and Morocco. However, by mid-2018, it is confirmed that 65 countries have taken significant measures onto creating domestic ABS legislation, policy or administrative mechanism, as envisaged in Articles 5.2 and 5.5 of Nagoya Protocol. Beyond the creation of laws or policies, the following section examines the implementation of legal frameworks in various countries around the world.

\subsection{Domestic Laws with Provisions on Mandatory Benefit-Sharing with ILCs}

According to Medaglia, Perron-Welch and Phillips (2014), a benefit-sharing agreement has been established and that the agreement is fair and equitable to all parties. Many ABS regulations include provisions concerning both monetary and non-monetary benefits (e.g. in the regulations of Kenya, Bhutan, and India). South Africa is reported to have established a mechanism to manage the monetary benefits, so that all money due to stakeholders in terms of any benefit-sharing agreement must be paid into the Bioprospecting Trust Fund (Medaglia, Perron-Welch \& Phillips, 2014). Yet while the majority of domestic laws include provisions governing benefit-sharing, whether these laws require benefits to be routed to Indigenous people and local communities must be examined.

The academic/research institutions were asked whether the Parties would adequately incorporate mandatory benefit-sharing with ILCs into their respective legislative, administrative or policy measures (Table 1: q.5). Interestingly, $50 \%$ of academic/research institutions indicated that only some Parties would make benefit-sharing to ILCs mandatory in their legislative, administrative or policy measures (Table 1: q.5). Nearly one-third (30\%) of academic/research institutions replied that "most of the governments neglect their respective ILCs" (Table 1: q.5). A smaller percentage (10\%) of surveyed academic institutions said that all Parties would make benefit-sharing to ILCs mandatory in their legislative, administrative or policy measures; and same percentage (10\%) highlighted that all or some Parties would make benefit-sharing to ILCs mandatory in their legislative, administrative or policy measures, but with their bias against Indigenous people (Table 1: q.5). As respondents, one-fourth (25\%) of CSOs indicated that only some Parties would make benefit-sharing to ILCs mandatory in their legislative, administrative or policy measures (Table 1: q.5). The same percentage (25\%) of CSOs conveyed that all Parties would make benefit-sharing to ILCs mandatory in their legislative, administrative or policy measures (Table 1: q.5); similarly, one-quarter (25\%) of CSOs highlighted that all or some Parties would make benefit-sharing to ILCs mandatory in their legislative, administrative or policy measures, but with their bias against Indigenous people (Table 1: q.5). Furthermore, 25\% of CSOs stated that "most of the governments neglect their respective ILCs" (Table 1: q.5). On the same question, one-third (33.3\%) of concerned individuals pointed out that only some Parties would make benefit-sharing with ILCs mandatory in their legislative, administrative or policy measures (Table 1: q.5). A small percentage (16.7\%) of individuals said that all Parties would make benefit-sharing with ILCs mandatory in their legislative, administrative or policy measures (Table 1: q.5). Similarly, one-third (33.3\%) of individuals underscored that all or some Parties would make benefit-sharing with ILCs mandatory in their legislative, administrative or policy measures, but with their bias against Indigenous people (Table 1: q.5). Lastly, 16.7\% of concerned individuals emphasized that "most of the governments neglect their respective ILCs" (Table 1: q.5).

The foregoing analysis indicates that about half of academic/research institutions thought that only some Parties would make benefit-sharing with ILCs mandatory in their legislative, administrative or policy measures. Moreover, a significant ratio of responding academic/research institutions believed that most of governments in the world neglect their respective ILCs. The responses of CSOs as to whether the Parties would adequately incorporate benefit-sharing with concerned ILCs into their respective legislative, administrative or policy measures were split into equal groups. Therefore, no single conclusion may be drawn as a prevailing trend. A significant ratio of individuals stated that some Parties would make benefit-sharing with ILCs mandatory in their legislative, administrative or policy measures. The same proportion of individuals indicated that all or some Parties would make benefit-sharing with ILCs mandatory in their legislative, administrative or policy measures, but with their bias against Indigenous people. Observations confirm the same.

For example, Part 5 (Article 33 to 43) of Australia's Biodiversity Act 2004, No. 19, addresses benefit-sharing mechanisms in detail, without any reference to Indigenous people. However, Section 8A.08(i) ${ }^{13}$ of Australia's Environment Protection and Biodiversity Conservation Regulations 2000 (Statutory Rules 2000 No. 181) mentions that

13 It reads: "a statement regarding benefits to be provided or any agreed commitments given in return for the use of the indigenous people's knowledge". 
there should be an agreement to share the benefits with Indigenous people. Similarly, Part 4 (Article 27 to 32) of Northern Territory of Australia Biological Resources Act 2006 focuses on benefit-sharing agreements, which do not require benefit-sharing with Indigenous people. Likewise, rule 20 of India's Biological Diversity Rules, 2004 describes the mechanism for benefit-sharing; however, it lacks any provision guaranteeing benefit-sharing with ILCs. Similarly, clause 5.1 of Bhutan's Access and Benefit Sharing Policy 2014 explicitly provides for the fair and equitable sharing of benefits arising from the utilization of genetic resources and associated TK but does not state whether ILCs are to be given benefits mandatorily.

\subsection{Participation of ILCs in Domestic Law-Making}

Academic/research institutions were also asked: "Is there any obligation on Parties, under the Nagoya Protocol, to invite participation of their ILCs in the process of creating/formulating/ changing of their legislations, rules, regulations, policies, guidelines, etc. guaranteeing the sharing of benefits to ILCs?" (Table 1: q.6). Half (50\%) of responding academic/research institutions stated that the Nagoya Protocol requires Parties to invite the participation of ILCs (Table 1: q.6). On the other hand, $30 \%$ of academic/research institutions responded that the Nagoya Protocol does not provide any obligation on Parties (Table 1: q.6). On the same question, half (50\%) of responding CSOs stated that the Nagoya Protocol requires Parties to invite the participation of ILCs (Table 1: q.6). On the other hand, 37.5\% of CSOs responded that the Nagoya Protocol does not place any obligation on Parties (Table 1: q.6). However, a further $12.5 \%$ of surveyed CSOs did not respond to the question. Surveyed individuals showed opposite trends in their responses to this question. Half (50\%) of responding individuals stated that the Nagoya Protocol requires Parties to invite the participation of ILCs (Table 1: q.6). On the other hand, the remaining half (50\%) of individuals responded that the Nagoya Protocol does not place any obligation on Parties (Table 1: q.6).

In relation to the Parties' obligations under the Nagoya Protocol, the academic/research institutions surveyed have mixed opinions about the effectiveness of the Nagoya Protocol in influencing Parties to ensure the participation of ILCs in the process of creating/formulating/changing their legislation, rules, regulations, policies, and guidelines to guarantee benefit-sharing with ILCs. The majority of CSOs stated that the Nagoya Protocol is effective in influencing Parties to ensure the participation of ILCs; however, a significant proportion of CSOs surveyed denied that the Nagoya Protocol requires Parties to invite the participation of ILCs in the process of creating/formulating/changing their legislation, rules, regulations, policies, and guidelines, guaranteeing benefit-sharing with ILCs. Likewise, respondent individuals hold opposing opinions about the effectiveness of the Nagoya Protocol in influencing Parties to ensure the participation of ILCs.

The participation of ILCs in the domestic law-making process may be possible only if sovereign nations recognize ILCs per se and uphold their rights as primary stakeholders of the access and benefit-sharing regime. With this notion in mind, Asian countries were approached to express their opinions about the recognition of ILCs in their domestic ABS laws or policies. The majority of competent national authorities (40\%) of the responding countries - India, Vietnam, Philippines and Russia - affirmed the recognition of ILCs 'to a large extent' within their national ABS policy/law on users' access to genetic resources and traditional knowledge, and on the sharing of benefits arising out of utilization of genetic resources (Table 2: q.1). Similarly, two countries (20\%) - Bangladesh and China - affirmed the recognition of ILCs 'to some extent' in national ABS policy/law (Table 2: q.1). 30\% of the responding countries - Lao, Brunei and Mongolia - stated that there is no recognition of ILCs in their national ABS policy/law (Table.2: q.1). Finally, Thailand showed no awareness of the issue, while Nepal and Timor did not respond to the question. Thus, a large proportion of responding countries $(60 \%$ in total) responded 'affirmatively' regarding the recognition of ILCs in national ABS policy/law.

Subsequently, the direct participation of ILCs in the domestic ABS law-making process was confirmed by competent national authorities in 12 countries. India and the Philippines (18\% of the respondent countries) confirmed the active participation of ILCs in national ABS law/policy making to a great extent (Table 2: q.2). Competent national authorities of Thailand, Lao, Vietnam and Brunei (36\% of the respondent countries) confirmed the participation of ILCs in national ABS law/policy making to some extent (Table 2: q.2). Two countries - Mongolia and China - out of the 12 countries surveyed (18\%) clearly refused any participation by ILCs in national ABS law/policy making (Table 2: q.2). Lastly, three countries - Nepal, Bangladesh and Russia - out of the surveyed 12 countries (27\%) were unaware of the participation of ILCs in national ABS law/policy making (Table 2: q.2). Timor did not respond the question at all. Wherever the participation of ILCs in national ABS law/policy making has been reported is needed to be weighed as active or passive participation (Table 2: q.3). Respondents have observed that the State shows a pseudo-participation of the ILCs in national ABS law/policy making. India, the Philippines and Brunei (30\% out of the 12 respondents) said that the participation of ILCs was/is 'active' (Table 2: q.3); while the same participation has been reported as 'passive' by Thailand, Lao and Vietnam (30\% out of the respondents). The responses of the various competent national authorities of the countries surveyed indicate that a total of $60 \%$ of the countries have a record of the involvement of ILCs to a great extent or to some extent. Half of these countries reported 'active participation' of ILCs and half reported 'passive participation'. 
Likewise, the concerns and viewpoints of ILCs were, to a great extent, respected, integrated or incorporated into national ABS policy/law, according to national competent authorities of India and Brunei (20\% of surveyed countries) (Table 2: q.4), while $60 \%$ of competent national authorities (of Bangladesh, Thailand, Lao, Vietnam, Philippine and Russia) stated that the concerns and viewpoints of ILCs were integrated or incorporated to some extent (Table 2: q.4). Two countries (20\% of respondents) - Mongolia and China - responded negatively on the question, whereas Nepal and Timor did not respond at all (Table 2: q.4). Therefore, it is understood from the responses of competent national authorities that the concerns and viewpoints of ILCs have been respected, integrated or incorporated into the national ABS policy/law to great or to some extent by the majority ( $80 \%$ ) of surveyed countries.

In conformity with the responses of academic/research institutions, CSOs and concerned individuals, and in contrast to the responses of CNAs of surveyed countries, the report of the Joint Submission of the Grand Council of the Crees et al. (2011) reiterates that the Nagoya Protocol does not guarantee the right to the full and effective participation of ILCs when Parties take legislative, administrative or other measures in relation to genetic resources and traditional knowledge. In the context of the participation of ILCs in domestic lawmaking, the only reference in the operative provisions to the term "participation" is in Article 12(2) ${ }^{14}$ of the Protocol ${ }^{15}$. Notably, the UNDRIP contains "more than 20 provisions affirming indigenous peoples' right to participate in decision-making" with respect to relevant international forums and domestic measures ${ }^{16}$. However, the Nagoya Protocol addresses the participation of ILCs in weak terms, using inappropriate qualifying language (Joint Submission of Grand Council of the Crees et al., 2011). Moreover, Indigenous peoples and local communities still continue to face dispossession, marginalization, biopiracy, and other forms of exploitation (Vedavathy, 2010).

\subsection{Sharing of Received Benefits by States with ILCs}

Under Article 5.2 and Article 5.5 of the Nagoya Protocol, each country's ABS legislation/policy must provide for benefit-sharing with concerned ILCs in a fair and equitable way. In the context of benefit-sharing by the Parties, academic/research institutions were posed the question: "Considering the fact that most Parties do not truly respect, recognize and enforce the rights of their own indigenous people, will the benefits received by provider Parties be further shared with their respective ILCs holding the accessed/utilized genetic resource or associated ITK?" (Table 1: q.7). A majority $(60 \%)$ of the surveyed academic/research institutions confirmed that only some provider countries would share the benefits with ILCs in due quantum (Table 1: q.7). A significant proportion (20\%) of academic/research institutions had doubts that any benefit would be shared with ILCs (Table 1: q.7). A further 10\% of academic/research institutions stated that all provider countries would share the benefits with ILCs in due quantum (Table 1: q.7), while another 10\% stated that all or some provider countries would share the benefits with ILCs, but a little (Table 1: q.7). Similarly, CSOs were posed the same question. The majority (50\%) of CSOs surveyed confirmed that only some provider countries would share the benefits with ILCs in due quantum (Table 1: q.7). On the other hand, 25\% of CSOs had doubts that any benefit would be shared with ILCs (Table 1: q.7). The remaining $20 \%$ of CSOs stated that all provider countries would share benefits with ILCs in due quantum (Table 1: q.7). Finally, concerned individuals were also asked the same question. Nearly one-third (33.3\%) of those surveyed stated that all or some provider countries would share benefits with ILCs, but a little (Table 1: q.7). The majority (66.7\%) of individuals had doubts that any benefit would be shared with ILCs (Table 1: q.7).

Thus, in the context of benefit-sharing by Parties with ILCs, while some of the responding academic/research institutions and CSOs doubted that benefits would be shared with ILCs, the majority of academic/research institutions and CSOs reiterated that only some provider countries would share benefits with ILCs in due quantum. By contrast, the majority of responding individuals doubted that benefits would be shared with ILCs. However, a significant minority of responding individuals reiterated that all or some provider countries would share benefits with concerned ILCs in due quantum.

14 Article 12(2) reads: "Parties, with the effective participation of the indigenous and local communities concerned, shall establish mechanisms to inform potential users of traditional knowledge associated with genetic resources about their obligations, including measures as made available through the Access and Benefit-sharing Clearing-House for access to and fair and equitable sharing of benefits arising from the utilization of such knowledge."

15 In the preamble of the Nagoya Protocol, the sole reference to "participation" pertains to women: "Recognizing also the vital role that women play in access and benefit-sharing and affirming the need for the full participation of women at all levels of policy making and implementation for biodiversity conservation".

16 Human Rights Council, Progress Report, supra note 159, where such provisions are said to be "articulated as, inter alia: (a) the right to self-determination; (b) the right to autonomy or self-government; (c) indigenous peoples' "right to participate"; (d) their "right to be actively involved"; (e) States' duty to "obtain their free, prior and informed consent"; (f) the duty to seek "free agreement" with indigenous peoples; (g) the duty to "consult and cooperate" with indigenous peoples; (h) the duty to undertake measures "in conjunction" with indigenous peoples; and (i) the duty to pay due "respect to the customs" of indigenous peoples." 
These results indicate that opinions are mixed in this context. Inference drawn from this analysis of opinions guides us to consider that it is an injustice of the Parties if the monetary benefits are not percolated duly to the ILCs. The Nagoya Protocol clearly sets out the responsibility of States to share the benefits from the utilization of genetic resources or associated TK. Yet some respondents pointed out that duly sharing of benefits with ILCs would happen as countries underwent decentralization of governance at the local level, noting that when people are aware, they tend to assert their rights. Some of the respondents assume that many/most domestic ABS laws will stipulate that MATs be completed with ILCs, meaning that a part or all the benefits would go to ILCs without being channeled through the financial system of the State. However, in reality, this is not the case.

Surveyed countries were also asked the question: "does your country's ABS legislation/policy provide for sharing benefits with concerned ILCs in a fair and equitable way, as envisaged in Article 5.2 and Article 5.5 of the Nagoya Protocol". India and the Philippines (20\% of responding countries) responded positively, while $30 \%$ of the responding countries (namely Mongolia, Russian and China) responded negatively (Table 2: q.2). Vietnam stated that its ABS law/policy provides for benefit-sharing with concerned ILCs, but not in a fair and equitable way. A sizeable proportion of responding countries (40\%) was unaware of the issues, including Bangladesh, Thailand, Lao and Brunei (Table 2: q.2). Nepal and Timor Leste did not answer the question. Although Indian authorities have confirmed that India's ABS legislation/policy provides for benefit-sharing with concerned ILCs in a fair and equitable way, observations of first author do not confirm the existence of a fully evolved mechanism for benefit-sharing in a fair and equitable manner. Thus, only one-third of the countries surveyed have a system in place or a commitment to share the acquired benefits with ILCs in a fair and equitable way, as envisaged in Article 5.2 and Article 5.5 of the Nagoya Protocol.

Some countries have developed or are in the process of developing national legislation or administrative measures to regulate not only access to genetic resources and TK, but also the routing of the benefits from users to providers. Governments usually mediate this process, and no monetary benefit can pass to the provider ILC without being channeled through the government's competent national authority or other mechanism. In most of the cases, such as in India, the monetary benefits first go to the government authority, and only if the government authority allows, do the benefits eventually reach (only partially) the provider ILCs. Indeed, in most of cases, governments retain all the benefits, chiefly in situations of blurred ownership claims by an ILC over the accessed/utilized genetic resource or TK. However, in situations where ILCs are ill-informed, they may fail to exercise any claim over the accessed bioresources, and the State may act unilaterally to execute the ABS agreements with providers, thereby excluding ILCs from the process.

\subsection{Mechanisms of Channeling Received Benefits to ILCs}

The majority of the countries that have created domestic ABS laws have included benefit-sharing provisions within these laws. However, the benefits to percolate to the ILCs adequately is likely a mechanism established in the legal framework or practice of large majority of nations. To verify this notion, surveyed academic/research institutions were asked how the benefits would be shared by provider Parties (usually developing countries) with Indigenous people and/or local communities holding the genetic resource or associated TK being accessed/utilized (Table 1: q.8). The majority of surveyed academic institutions (60\%) indicated that it depends on the Parties how they develop a mechanism and what type of mechanism they develop (Table 1: q.8). However, 20\% of academic/research institutions gave several suggestions. In the same way, three CSOs (37.5\%) did not respond in response to the question, while the same number of CSOs (37.5\%) indicated that it depends on the Parties (Table 1: q.8). Significantly, 25\% CSOs gave several suggestions. Unlike CSOs, the majority (50\%) of individuals surveyed indicated that it depends on the Parties how they develop a mechanism and what mechanism they develop (Table 1: q.8). $25 \%$ of surveyed individuals gave several suggestions.

Assuming that user Parties (usually developed countries) would instead directly share the benefits with ILCs, bypassing their respective State (provider Party), the academic/research institutions, CSOs and concerned individuals largely agreed that how benefit-sharing mechanisms are developed depends on the Parties, in accordance of their domestic ABS laws or frameworks. However, some suggestions were provided:

- If the genetic resource is acquired from private field/community/government, the owner of resources should receive $50 \%$ of the benefits, and the remaining benefit should go towards the administrative and management costs associated with the process.

- ILCs should be made aware of their rights under the CBD and the Nagoya Protocol, and they should be allowed to decide which mechanisms to employ.

- If a country defines TK of ILC as State property, acting as a provider country, then the country should distribute the benefits it receives to the ILCs. If the TK belongs to a particular ILC, they are the owner and they should make decisions concerning the resources in question, including with respect to PIC, MAT and receiving benefits directly. 
Countries were also asked: how would the benefits received by your country further be shared with your Indigenous people and/or local communities holding the genetic resource or associated ITK being accessed/ utilized? 10 out of 12 countries responded to this question (Table 2: q.3). Competent national authorities of three countries (30\%) - Lao, Russia and China - did not answer, while another three countries (30\%) - Bangladesh, Thailand and Mongolia - stated that their countries do not know about developing such mechanism (Table 2: q.3). However, the national competent authorities of four countries (40\%) - India, Vietnam, the Philippines and Brunei - gave suggestions for an alternative mechanism to further share received benefits with ILCs (Table 2: q.3).

Several examples are illustrative. For instance, Costa Rica is reputed to have the most advanced ABS laws in the world (Jospeh, 2010). INBio, the agency responsible for carrying out bioprospecting agreements, executed more than 25 bioprospecting agreements respecting the bioresources belonging to 12 Indigenous territories. Reportedly, the Ministry of Environment and Energy (MINAE) of Costa Rica received US\$790,649 between 1991 and 2000 on account of bioprospecting. Yet, the Indigenous people inhabiting those territories received no benefit, and the money was instead invested in conservation activities on the uninhabited island of Coco (Richerzhagen, 2010). Ultimately, no benefit was realized by the ILCs in this case. Likewise, in case of India, Section 21(2) of the Biological Diversity Act 2002 elaborates the mechanism of benefit-sharing with local communities. The National Biodiversity Authority (NBA) has created 3-tier Funds to receive the monetary benefits from the users of biological resources. The money received in these funds from grants, loans, charges and royalties is used to channel benefits to the benefit claimers, as well as to conservation, the promotion of bioresources, and the development of areas from where such bioresources or associated TK has been accessed (RIS, 2014). The NBA had signed 117 ABS agreements ${ }^{17}$ as of August 2013. In India, the general practice is that the NBA collects annually 2-5 percent of gross ex-factory sales revenue of the products derived from bioresources obtained from India during the period of the agreement. The NBA has received more than Indian Rs. 4.3 million in royalties from seven agreements (out of 117), of which only Rs. 20,000 has been sent to a biodiversity management committee ${ }^{18}$ (BMC). The rest of the money remained with the NBA (RIS, 2014). The amount of money that reached local communities was a mere 0.46 percent. These two examples highlight the reality of benefit-sharing with ILCs in two countries whose ABS mechanisms have been touted as best practices.

\subsection{Rights of Indigenous People in Domestic Legislation}

In regard to fair and equitable benefit-sharing arising from the use of genetic resources, Article 5.2 of the Protocol only provides for benefit-sharing in regard to "established" rights of Indigenous people and local communities. This Article emphasizes the phrase "in accordance with domestic legislation regarding the established rights of these indigenous and local communities over these genetic resources". In this regard, the report of the Joint Submission of Grand Council of the Crees et al. (2011) reiterates that

the reference to 'established' rights might only refer to situations where a particular indigenous people or local community can demonstrate that its right to genetic resources is affirmed by domestic legislation, agreement or judicial ruling. ${ }^{19}$ If such rights are not so proved, they might not receive any protection under the Nagoya Protocol - regardless of how strong the evidence that such rights exist. ${ }^{20}$ Should the term 'established' be interpreted in such a restrictive manner, most indigenous peoples worldwide could be denied their rights to genetic resources. If so, widespread dispossession and impoverishment would result. In light of such prejudicial factors, the Articles 5.2 and 6.2 are incompatible with the overall objectives and duties of States in the Convention and Protocol.

The interpretation of the phrase "established rights" was also polled through the opinion survey. Academic/research institutions were asked: "What do you understand from the phrase "in accordance with domestic legislation regarding the established rights of these indigenous and local communities over these genetic resources' in Article 5.2 of the Nagoya Protocol?" (Table 1: q.9). Out of the responding academic/research institutions, eight respondents (80\%) gave their interpretations and views, which are included in the analysis of this section (Table 1: q.9). Similarly, the majority

17 Status as on 31 August, 2013 available at http://nbaindia.org/text/24/TOTALAPPLICATIONRECEIVED.html

18 BMC is local community level institution.

19 For example, in Canada, Rio Tinto Alcan Inc. v. Carrier Sekani Tribal Council, 2010 SCC 43, where the Supreme Court of Canada made the distinction between "established" rights and "unproven" rights. The Court indicated at para. 41that, in the face of proposed government action, both types of "existing" rights require prior consultation to protect such rights from harm: The claim or right must be one which actually exists and stands to be affected by the proposed government action. This flows from the fact that the purpose of consultation is to protect unproven or established rights from irreversible harm as the settlement negotiations proceed ... [emphasis added]

20 Haida Nation v. British Columbia (Minister of Forests), [2004] 3 S.C.R. 511, para. 37: "The law is capable of differentiating between tenuous claims, claims possessing a strong prima facie case, and established claims." 
(87.5\%) of surveyed CSOs expressed their interpretations (Table 1: q.9), along with 66.7\% of concerned individuals. These are also included in the analysis of this section (Table 1: q.9).

Repeated references to domestic ABS legislation in the Nagoya Protocol recognize national sovereignty over genetic resources and empower the Parties to interpret the ABS regime in their own fashion and to treat respective ILCs at their discretion. Since these references are consequential for the implementation of domestic measures affecting ILCs, interpretations of the phrase "in accordance with domestic legislation regarding the established rights of these indigenous and local communities over these genetic resources" in Article 5.2 of the Nagoya Protocol were assessed through the questionnaire. Interestingly, a variety of interpretations were made by respondents, such as:

- Due to frequent references to domestic legislation in the Nagoya Protocol, it seems that countries' domestic legislation is a decisive factor in ascertaining the rights of ILCs in ABS processes.

- Domestic legislation should recognize/protect the rights of ILCs over genetic resources, and benefit-sharing mechanisms should transparently involve human rights and Indigenous rights. ILCs themselves cannot defend their rights in most cases and may easily be cheated by multinational corporations (MNCs).

- This part of the Nagoya Protocol is an attempt to pass the buck to the State. If the State does not have a well-developed charter of rights for Indigenous people (and most countries do not), then the Nagoya Protocol will not apply.

- Domestic legislation is decisive in this case. It pertains to establishing rights over genetic resources and TK by statutory legal arrangement.

- The rights of ILCs over genetic resources shall be in accordance with relevant domestic legislation, such as the Constitution and the law of regional national autonomy (for example, in China).

- It pertains to local laws/government laws in force with respect to the rights and entitlements of Indigenous people over local genetic resources.

- In most of the countries like India, ILCs are unable to read or understand the legislation. The laws are made by bureaucrats or legal experts who have very little understanding of ILCs or concern for them.

- ILCs are granted rights on determining the use - and hopefully also ownership rights - over their genetic resources. In this regard, Article 5.2 of the Nagoya Protocol is fundamentally different from Article 5.5, which does not address domestic legislation. This is because the ownership of TK is a human rights issue (see UNDRIP). Ownership over genetic resources is a classical property rights issue which is different from human rights.

- Each Party is free to establish a domestic law on rights of ILCs over genetic resources; if such a law has been established, then it has to be taken into account in the benefit-sharing process. But nothing is said about the context, content and extent of that legislation.

- It is a very cryptic reservation regarding Indigenous rights to land and resources.

- This established right of Indigenous people and local communities means the right is a prior, previous and existing right before domestic legislation was passed. We should only to confirm or ensure this right.

It is hard to imagine that communities can protect their knowledge and genetic resources if they do not have adequate recognition of their rights (Posey et al., 1996; Dutfield, 2013; Tobin, 2013). Moreover, States will arguably find it difficult to protect genetic resources supposedly under their sovereign control if they have not made efforts to involve ILCs. Undoubtedly, Indigenous peoples' assertions need to be heard and they have a right to adequate political space, self-determination, land and biological resources (Posey et al., 1996; Dutfield, 2013; Tobin, 2013).

\section{Conclusion}

Under Article 5.2 of the Nagoya Protocol, the users of genetic resources must share the benefits resulting from the utilization of such resources with provider Parties in a fair and equitable manner. In accordance with Article 5.5, the Nagoya Protocol can be considered effective only when it ensures the flow of benefits to "voiceless" Indigenous communities. The analysis in the preceding section indicates that, considering the power imbalance between users (usually in developed countries) and providers (usually in developing countries), fair benefit-sharing is not guaranteed. Since the mechanism of benefit-sharing is subject to negotiation between two parties and to the power relations between user and provider, fair and equitable sharing often depends on the trade relations of two negotiating nations and their relative power positions on economic and ecological fronts.

In the process of benefit-sharing, PIC and MAT are critical points at which principles of equity and justice must be embedded. The findings in this article highlight that the present neo-liberal framework works primarily on the basis of 
market principles and hence the question of justice or equity does not seem to prevail. MAT can be developed with no guarantee of the integration of justice and equity concerns. Again, the power asymmetry between two negotiating nations or between user and provider results in restraining the fair and equitable sharing of benefits. Whether or not justice and equity concerns are incorporated depends on the power equation, as well as on the trade needs of both sides. The same applies to the development of MAT between the Parties or between users and providers. However, enhancing the capacities of weak parties may alter their bargaining position.

The backbone of the Nagoya Protocol is the domestic law of different countries, which should guarantee benefit-sharing with concerned ILCs in a fair and equitable way. Till 2018, only 65 countries had taken significant measures on domestic ABS legislation, policy or administrative mechanisms, as envisaged in Articles 5.2 and 5.5 of the Nagoya Protocol. However, in addition to creating laws or policies, it is also necessary to examine the implementation of legal frameworks in various countries. An additional aspect of implementation is the legal space in domestic ABS regimes for mandatory benefit-sharing with ILCs, but few nations have done this.

Participation of ILCs in lawmaking processes may be a new phenomenon in many countries, but it is essential for the development of ABS rules. Another essential prerequisite to this is the opening up of more dialogue between Indigenous peoples and the governments where they reside. Only then will States accommodate the rights and interests of ILCs in their respective ABS legislation. Moreover, there is a need to clarify and sharpen Indigenous positions on the Nagoya Protocol, as well as a need to continually advocate in relevant CBD bodies for the full and effective participation of ILCs in domestic ABS legislation.

The Nagoya Protocol fails to affirm the right to full and effective participation of ILCs when Parties take legislative, administrative or other measures in relation to genetic resources and traditional knowledge. When obligations to ILCs are mentioned, it is often in weak terms. Yet, the UNDRIP contains "more than 20 provisions affirming Indigenous peoples' right to participate in decision-making" in relevant international forums and with respect to domestic measures (UN, 2010).

In the context of benefit-sharing, governments usually mediate the process. In most cases, no monetary benefit flows to the provider ILCs without passing first through the government's national competent authority (NCA) or other mechanism. Only if the government authority allows will the benefits eventually be realized by the provider ILCs. Yet in most of cases, governments retain the benefits (Arjjumend, 2015; Arjjumend et al., 2016). It is an injustice of the States if the monetary benefits are not shared duly with the ILCs (Arjjumend et al., 2017). The sharing of benefits depends on the governments how they develop a mechanism and what mechanism they develop in accordance with their domestic ABS laws or frameworks. Benefit sharing to ILCs, equity and justice concerns and ILCs participation in decision-making processes are restrained partly due to the fact that repeated references to domestic ABS legislation in the Nagoya Protocol recognize national sovereignty, which in turn empowers the Parties to interpret the ABS regime in its own fashion and treat respective ILCs at the State's discretion (Koutouki \& von-Bieberstein, 2012; von-Bieberstein \& Koutouki, 2011). So, if the State does not have a well-developed charter of rights for the Indigenous people (and most countries do not), the provisions of the Nagoya Protocol do not apply. Domestic legislation is decisive in this case.

\section{Recommendations}

- Governments of user Parties should establish robust mechanisms of sharing the benefits on fair and equity principles with the providers of the biological resources and associated TK. Economic and trade negotiations between two Parties of two nations should not override the development and livelihood concerns of local communities especially Indigenous peoples.

- Benefit sharing process must ensure mandatory PIC and MAT to be negotiated in environment of symmetrical power relations of two Parties. Justice and equity concerns need to be the crosscutting elements in entire process of benefit sharing. Capacity building of Indigenous peoples and provider Parties (especially developing countries) should be made essential before actually developing PIC and MAT.

- All Parties to CBD and Nagoya Protocol need to create domestic ABS laws, policies or administrative measures with essential aspects of fair and equitable sharing of benefits with respective ILCs. Adequate representation and participation of Indigenous peoples and local communities should be ensured not only in law making process but also in the execution of mechanisms and procedures.

- Although the Nagoya Protocol itself overpowers the State sovereignty over the natural resources and repeatedly calls for reinforcement of domestic ABS laws, overall benefit sharing system must develop fair and equitable system involving due justice to the Indigenous peoples in conformity of UNDRIP, which is the foundation of Nagoya Protocol. 


\section{Acknowledgement}

The authors duly acknowledge Frederic Perron-Welch, Technical Officer, PIP Secretariat, World Health Organization, Geneva (Switzerland) and the Senior Legal Fellow at CISDL Canada for his intensive editing of the text of this paper.

\section{References}

Arjjumend, H. (2015). Analysis of India's ABS Regime in Context if Indigenous People and Local Communities. International Journal of Applied Research \& Studies, IV(1).

Arjjumend, H., Alam, S., Koivurova, T., \& Shishatskiy, N. G. (2016). Comparative analysis of access and benefit sharing regimes in India and Russia in context of indigenous peoples and local communities. Journal of Siberian Federal University: Humanities \& Social Sciences, $1(2016.9), \quad 265-290$. https://doi.org/10.17516/1997-1370-2016-9-1-265-290

Arjjumend, H., Koutouki, K., Alam, S., \& Koivurova, T. (2017). The Space for Indigenous People and Local Communities: Participation in Policy Making and Benefit Sharing Negotiations. World Affairs: Journal of International Issues, 21(4), 56-72. http://www.worldaffairsjournal.com/content.php

Broggiato, A., Dedeurwaerdere, T., Batur, F., \& Coolsaet, B. (2015). Introduction. Access Benefit-Sharing and the Nagoya Protocol: The Confluence of Abiding Legal Doctrines. In Coolsaet, B., Batur, F., Broggiato, A., Pitseys, J., \& Dedeurwaerdere, T. (Eds.), Implementing the Nagoya Protocol: Comparing Access and Benefit-Sharing Regimes in Europe. Leiden/Boston: Brill Nijhoff. https://doi.org/10.1163/9789004293212_002

Coolsaet, B. (2015). Conclusion. Comparing Access and Benefit-Sharing in Europe. In Coolsaet, B., Batur, F., Broggiato, A., Pitseys, J., \& Dedeurwaerdere, T. (Eds.), Implementing the Nagoya Protocol: Comparing Access and Benefit-Sharing Regimes in Europe. Leiden/Boston: Brill Nijhoff. https://doi.org/10.1163/9789004293212_017

DeMunck, V. C., \& Sobo, E. J. (Eds.) (1998). Using methods in the field: a practical introduction and casebook, Walnut Creek, CA: Alta Mira Press.

DeWalt, K. M., \& DeWalt, B. R. (2002). Participant observation: a guide for fieldworkers. Walnut Creek, CA: Alta Mira Press.

Dutfield, G. (2013). Transboundary resources, consent and customary law. Law, Environment and Development Journal, 9(2), 259-263.

Frein, M., \& Meyer, H. (2011). Nagoya Protocol on Access and Benefit Sharing (ABS) under the Convention on Biological Diversity (CBD), Background-Paper.D, Bonn: EED \& WWF-Germany.

Hufty, M. (2001). La gouvernance internationale de la biodiversité. Études internationales, 32(1), 5. https://doi.org/10.7202/704254ar

Joint Submission of Grand Council of the Crees et al. (2011). Nagoya Protocol on Access and Benefit Sharing: Substantive and Procedural Injustices relating to Indigenous Peoples' Human Rights. Expert Mechanism on the Rights of Indigenous Peoples Fourth session, Geneva, 11-15 July 2011. Agenda Item 4: Study on indigenous peoples and the right to participate in decision-making. http://quakerservice.ca/wp-content/uploads/2011/08/Expert-Mechanism-Study-re-IPs-Rt-to-Participate-Joint-Subm ission-on-Nagoya-Protocol-FINAL-GCC-et-al-July-6-11.pdf).

Jospeh, R. K. (2010). International Regime on Access and Benefit Sharing: Where Are We Now? Asian Biotechnology and Development Review, 12(3), 77-94.

Kawulich, B. B. (2005). Participant observation as a data collection method. Forum Qualitative Sozialforschung / Forum: Qualitative Social Research, 6(2), Art.43. http://nbn-resolving.de/urn:nbn:de:0114-fqs0502430.

Koutouki, K., \& von-Bieberstein, K. R. (2012). The Nagoya Protocol: Sustainable access and benefit-sharing for Indigenous and local communities. Vermont Journal of Environmental Law, 13, 513-535. https://doi.org/10.2307/vermjenvilaw.13.3.513

Medaglia, J. C., Perron-Welch, F., \& Phillips, F.K. (2014). Overview of National and Regional Measures on Access and Benefit Sharing: Challenges and Opportunities in Implementing the Nagoya Protocol, 3rd Edition. CISDL Biodiversity \& Biosafety Law Research Programme, Centre for International Sustainable Development Law (CISDL), Montreal.

Morgera, E., Buck, M. \& Tsioumani, E. (2012). The 2010 Nagoya Protocol on Access and Benefit-sharing in perspective implications for international law and implementation challenges. Series on Legal Studies on Access 
and Benefit-sharing, vol.1. Leiden/Boston: Martinus Nijhoff Publication. https://doi.org/10.1163/9789004217201_002

Morgera, E., Buck, M., \& Tsioumani, E. (Eds.) (2013). The 2010 Nagoya Protocol on Access and Benefit Sharing in Perspective: Implications for International Law and Implementation Challenges. Leiden: Martinus Nijhoff. https://doi.org/10.1163/9789004217201

Morgera, E., Tsioumani, E., \& Buck, M. (2014). Unraveling the Nagoya Protocol: a commentary on the Nagoya Protocol on access and benefit-sharing to the Convention on Biological Diversity. Series on Legal Studies on Access and Benefit-sharing. London: Brill. https://doi.org/10.1163/9789004217188

Posey, D. A., Dutfield, G., Plenderleith, K., da Costa e Silva, E., \& Argumedo, A. (1996). Traditional Resource Rights: International Instruments for Protection and Compensation for Indigenous Peoples and Local Communities. International Union for Conservation of Nature (IUCN), Gland.

Prip, C., \& Rosendal, K. (2015). Access to genetic resources and benefit-sharing from their use (ABS) - state of implementation and research gaps, pp.38. FNI Report 5/2015 commissioned by PBL Netherlands Environmental Assessment Agency. Fridtjof Nansen Institute (FNI), Oslo. https://doi.org/10.13140/RG.2.2.22287.18088

Raustiala, K., \& Victor, D. G. (2004). The Regime Complex for Plant Genetic Resources. International Organization, 58(2004), 277-309. https://doi.org/10.1017/S0020818304582036

Richerzhagen, C. (2010). Protecting Biological Diversity: The Effectiveness of Access and Benefit Sharing Regimes. London: Routledge.

RIS (2014). National Study on ABS Implementation in India. Commissioned by the ABS Capacity Development Initiative in collaboration with the Government of India. Research and Information System for Developing Countries (RIS), India Habitat Centre, New Delhi.

Robinson, D. F. (2015). Biodiversity, Access and Benefit-Sharing: Global Case Studies, London: Earthscan/Routledge. https://doi.org/10.4324/9781315882819

Tobin, B. (2013). Bridging the Nagoya compliance gap: The fundamental role of customary law in protection of indigenous people's resource and knowledge rights. Law, Environment and Development Journal, 9(2), 142-162.

UN (2010). Progress report on the study on indigenous peoples and the right to participate in decision-making. Report of the Expert Mechanism on the Rights of Indigenous Peoples, Third session. A/HRC/EMRIP/2010/2. Human Rights Council, United Nations General Assembly, 17 May 2010. https://www2.ohchr.org/english/issues/indigenous/expertmechanism/3rd/docs/a_hrc_emrip_2010_2_en.doc

Vedavathy, S. (2010). Displaced and Marginalised: Protecting the Traditional Knowledge, Customary Laws and Forest Rights of the Yanadi Tribals of Andhra Pradesh. Herbal Folklore Research Centre, Tirupati, Andhra Pradesh, India. http://pubs.iied.org/pdfs/G02788.pdf.

von-Bieberstein, K. R., \& Koutouki, K. (2011). The Nagoya Protocol: Status of Indigenous and Local Communities. Legal Working Paper Series, Montreal: CISDL.

http://cisdl.org/public/docs/news/Koutouki_and_Von_Bieberstein_THE_NAGOYA_PROTOCOL_STATUS_OF_I NDIGENOUS_AND_LOCAL_COMMUNITIES.pdf 


\section{Annexure-I: Lists of Structured Interview Respondents}

1. List of Respondent Academic/Research Institutions: (1) Department of Ecology \& Environmental Sciences, Pondicherry University, India (represented by Dr. G. Poyya Moli); (2) Institut du développement durable et des relations internationals (IDDRI), France (represented by Dr. Veit Koester ); (3) State Institute of Panchayats and Rural Development, West Bengal, India (represented by Dr. Manab Sen); (4) Animal Science Research Institute of Iran (represented by Dr. Farhad Mirzaei); (5) Department of Civics and Politics, University of Mumbai, India (represented by Dr. Kannamma Raman); (6) INIIS, University of Bremen, Germany (represented by Ms. Ina Lehmann); (7) Nirmala College, Kerala, India (represented by Dr. Shaju Thomas); (8) International Centre for Integrated Mountain Development (ICIMOD), Kathmandu, Nepal (represented by Dr. Krishna Prasad Oli); (9) Law School, Wuhan University, Hubei Province, China (represented by Dr. Yiding Li); (10) Minzu University of China/ Chinese Research Academy of Environmental Sciences, China (represented by Dr. Xu Jing).

2. List of Respondent Civil Society Organizations: (1) Pan African Vision for the Environment (PAVE), Nigeria (represented by Anthony Akpan); (2) Natural Justice, South Africa (represented by Harry Jonas); (3) World Forum for Alternatives, Belgium (François Houtart); (4) SHARA, Himachal Pradesh, India (represented by Chuni Lal); (5) Rural Development Organization, Andhra Pradesh, India (represented by R. Gangi Reddy); (6) SGSA, Chhattisgarh, India (represented by R.K. Singh); (7) Prometra Kenya, Kenya (represented by Martha Njama); (8) LPSD, Vietnam (represented by Tran Thi Huong Trang).

3. List of Respondent Concerned Individuals: (1) Beli Ram Thakur, Himachal Pradesh (India); (2) Hartmut Meyer (Germany); (3) Ajay Bhan Singh, Madhya Pradesh (India); (4) María Julia Ochoa Jiménez (Colombia); (5) Dr. Aafaaque Ghani, Jammu \& Kashmir (India); (6) Susette Biber-Klemm (Switzerland).

4. List of Respondent CNAs: (1) National Biodiversity Authority, Ministry of Environment \& Forests, India [Mr. Balakrishnan Pisupati, Chairman (former)]; (2) Ministry of Environment and Forests, Bangladesh [Dr. Abu Saleh Mostafa Kamal, Deputy Secretary \& Focal Point for ABS/ICNP]; (3) Environment Division at Ministry of Forests and Soil Conservation, Nepal [Mr. Sagar Kumar Rimal, Under Secretary Technical and Chief of Biodiversity Section]; (4) Biotechnology and Ecology Institute, Ministry of Science and Technology, Lao PDR [Dr. Sourioudong Sundara, Director General]; (5) Biodiversity Conservation Agency, Vietnam [Ms. Hoang Thi Thanh Nhan, Deputy Director]; (6) Office of Natural Resources and Environmental Policy and Planning, Thailand [Dr. Sirikul Bunpapong, Director, Biological Diversity Division]; (7) Protected Areas and Wildlife Bureau, Department of Environment and Natural Resources, Philippines [Ms. Nermalie M. Lita, OIC, Wildlife Management Section, Wildlife Resources Division]; (8) HoB Centre, Ministry of Industry and Primary Resources, Brunei Darussalam [Mr. Mahmud Yussof, Deputy Director / Interim CEO]; (9) National University of East Timor, Timor Leste [Dr. Marcal Gusmao, Lecturer, Department of Agronomy, Faculty of Agriculture]; (10) Department of Nature and Ecology Conservation, Ministry of Environmental Protection, China [Mr. Zhang Wenguo, Director, Division of Biodiversity Conservation]; (11) Department of International Cooperation, Ministry of Natural Resources and Environment, Russian Federation [Mr. Akhmed Musaev, Senior Specialist-Expert, Division of International Conventions]; (12) Ministry of Environment and Green Development, Mongolia [Mr. Banzragch Tsesed, Director, Department of Sustainable Development and Strategy Planning]

\section{Copyrights}

Copyright for this article is retained by the author(s), with first publication rights granted to the journal.

This is an open-access article distributed under the terms and conditions of the Creative Commons Attribution license which permits unrestricted use, distribution, and reproduction in any medium, provided the original work is properly cited. 